\title{
"DISCRIMINATION" UNDER THE NATIONAL LABOR RELATIONS ACT
}

\author{
BY CHESTER C. WARD $\dagger$
}

AdMINISTRATION of the National Labor Relations Act ${ }^{1}$ has entered a new era under the first sharply-interpretative decisions of the Supreme Court ${ }^{2}$ just as certainly as application of the Act entered a new era under stimulus of the great constitutional decisions of April, 1937. The principal changes to evolve in the new phase will center about the National Labor Relations Board's doctrines of "discrimination" under the Act. They will be wrought chiefly by the Court's delineation of legitimate cause for discharge of employees under the Act ${ }^{5}$ and by the Court's creation of a new psychology regarding finality of the Board's findings of fact."

The heavy and direct impact of the Act on employers is through the mysteriously phrased unfair labor practice proscribed by Section $8(3)^{7}$ and characterized by the Board as "discrimination." The penalty for

†Assistant Professor of Law, George Washington University Law School; Associate Editor, LABOR RejatTons Reporter.

1. 49 Stat. 449 (1935), 29 U. S. C. $\$ \$ 151-66$ (Supp. 1937); hereinafter refertell to as the Act. The purpose and structure of the Act have already been widely discussed. A bibliography of recent references lists more than 50 articles and 25 books and paumphilets: NLRB ThIRD ANNuAl, RePoRt (1939) 289-92, continuing extensive chronologicallyarranged bibliography from SECOND ANwuAL RePoRT (1938) 169-72. A short non-technical, official explanation of the Act is contained in NLRB Firsr ANNust Rupont (1937) 9-13. For a graphic account of the Act in action, and of the emotional bias with which it is viewed, see The $G-D-L a b o r$ Board (Oct. 1938) ForTune 52. A sympathetic account of the general administration of the Act is contained in Bkooks, UNIONs or. Their Own Choosing (1939); a background story by Malcolm Ross, the Burard's Dic rector of Publications, rejoices in the enigmatic title, DEATr of A YALE MAN (1039).

2. N. L. R. B. v. Fansteel Corp., (1939) 6 U. S. L. WeEk 896; N. L. R. B. v. Sand: Manufacturing Co., (1939) 6 U. S. L. WEEK 887; N. L.R.B. v. Columbian Eunameling and Stamping Co., (1939) 6 U. S. L. WeEK 892, decided by Supreme Court, Fet. 27, 1939.

3. N. L. R. B. v. Jones \& Laughlin Steel Corp., and related cases, 301 U. S. 1 (1937).

4. Hereinafter referred as the Board or as NLRB.

5. All three of the decisions of Feb. 27,1939 , supra note 2 , turned fundannentally on this question.

6. In the Colmmbian and Sands cases, the Supreme Court for the first time ove's turned the Board's findings of fact. Prior to these reversals the Board's record of st1"* cesses before the Court had been so impressive that it was a frequent occurrence for employers to settle cases of alleged discrimination for amounts ranging from $\$ 10,100$ to $\$ 51,000$, without even going to hearing before the trial examiner. E.g.. Stearns Coal if Lumber Co., 11 NLRB, No. 40 (1939); National Tea Co., 9 NLRB, No. 25 (1938) $(\$ 51,000)$. Such settlements totaled $\$ 131,083.85$ in 1938 for the Board's Sccond Region (New York) alone. Report of Regional Director Elinore M. Herrick (1939) 4 L. R. R. 45,52 .

7. Quoted in full infra p. 1155. 
violation of Section $8(1)$, or (2), or $(5),{ }^{8}$ is an order to cease and desist. For violation of Section $8(3)$, however, the penalty has run as high as a quarter of a million dollars in a single case. ${ }^{0}$ Thus the arsenal of the Board, ordinarily restricted to a sort of verbal tear gas - the cease and desist order - is, in the case of violations of Section $S(3)$, implemented by a financial-armor-piercing projectile - the back pay order.

To employees, also, Section $8(3)$ is most crucial. If a union employee is fired, laid off, locked out, or demoted, he may file charges under this subsection and be ordered reinstated with back pay. Some employees have received back pay for as long as three and a half years, ${ }^{10}$ and they need not even look for other work to be entitled to such pay.11 From this point of view, Section $8(3)$ protects an employee's job, his living. Moreover, union officials must know, for the purposes of their strategy and tactics, what conduct will change the status of their members from striking employees entitled neither to back pay nor preferential reinstatement to the status of employees "discriminated" against, who are entitled to back pay and reinstatement. These things depend upon the construction of Section 8(3). Nor can non-union employees who do not choose to engage in collective action afford to remain, as they apparently are, uninformed as to what this subsection means. At a time when protection of minorities is much before the world, it is surprising that the function of Section 8(3) in protecting such workers has never been invoked. In a Statute which commands majority rule, ${ }^{12}$ Section $8(3)$ alone can prevent a union clothed by the Statute with dictatorial power from giving vent to a human-enough tendency toward seeking vengeance against employees who refused to join while the union was seeking its majority. ${ }^{13}$ For protection in situations where employer tactics directed against union members catch non-unionists in a cross-fire, Section $8(3)$ again is the unaffiliated employee's sole reliance. ${ }^{14}$

Tactically and practically, Section $8(3)$ appears to be the most important provision $^{15}$ of the entire Act, as to all persons affected - em-

8. Ibid.

9. N. L. R. B. v. Carlisle Lumber Co., 94 F. (2d) 138 (C. C. A. 94h, 1937), ccrt. denied, 304 U. S. 575 (1938); 99 F. (2d) 533 (C. C. A. 9th, 1938), cerl. denied, (1939) 6 U. S. L. WEEK 914.

10. In re Colorado Milling and Elevator Co., 11 NLRB, No. 16 (1939).

11. Western Felt Works, 10 NLRB, No. 31 (1938).

12. Section 9(a).

13. Developed infra pp. 1166 et seq.

14. Developed infra p. 1168.

15. Section $8(5)$, which makes it an unfair labor practice for an employer to refuse to bargain collectively, is the substantive section which embodies the ultimate purpose of the Act. See Latham, Federal Regulation of Collectie' Bargaining (1937) 6 Gzo. WASH. L. REv. 1; Wolf, The Duty to Bargain Collectia'dy (1938) 5 Law Aso Co:sresr. ProB. 242. The first four subsections of $\S 8$ are purposed to protect the collective bar- 
ployers, employees, and organizers. The Board has already handled a total of 20,000 cases involving 5,000,000 workers, ${ }^{10}$ and approximately two-thirds of all unfair labor practice complaints filed in 1938 invalved charges under Section 8(3).17 A pressing need exists, therefore, not only for an examination of the doctrines of "discrimination" evolved by the Labor Board, with emphasis on their revaluation in the light of the Supreme Court decisions, but also for a consideration of several important problems arising under the Act which have not as yet been adjudicated by either the Board or the courts.

\section{What is the Unfair Labor Practice under Section 8(3)?}

On the answer to this question hinges the employer's right to matintain discipline in the plant, now most disconcertingly vexed by uncertainty, and his right to select for discharge and hire, since the Court's decisions of February 27, 1939, protect expressly only the employer's property and contract rights. The employee's "right" to his job depends in large measure upon this definition. Perhaps the whole problem of the sitdown strike in connection with the Act could best have been settled on this issue. ${ }^{18}$ In any event, the question seems fairly raised, since the Board, in the great preponderance of its cases, administers stubsection (3) as if it read: it shall be an unfair labor practice for an employer "to discriminate because of union activity." 10 Indeed, the Board tends to use those very words when it is not concentrating on what it obviously considers merely formal findings or discussions. ${ }^{20}$ Actually, however, the words of the Statute are quite different.

The Statutory Wording of Section 8(3). Perhaps the best method, although one may suspect an unusual one, ${ }^{21}$ of understanding the com-

gaining process. Since this process will need progressively less protection as it hecomes more widely accepted, and as unions become stronger and more experienced, subsection (5) will eventually supplant the protective subsections in importance and in impact on employers. At present, however, that is not the case.

16. NLRB MoNthly Report (Feb. 1939) showed a cumulative total of 19,659 cases, "involving" 4,435,574 workers.

17. NLRB Third Annual Report (1939) 28.

18. Instead of on the issue of the Board's power to order reinstatement, which was the ultimate point of decision in the Fanstecl case, although the fundamental issuc was the employer's right to discharge employees because of their seizure of the company's property.

19. See infra pp. 1155 et seq. In its very first decision under the Act, In re Pennsylvania Greyhound Lines, Inc., 1 NLRB 1, 36 (1933) the Board introduced, with absolutely no explanation or reasoning, "discharge for union activity" as an additional alternative unfair labor practice to that expressed in the words of Section $S(3)$.

20. NLRB ThiRd Annual Report (1939) 81: "The Board's construction of the scope of $\S \$(3)$. . . briefly (is that) it forbids the employer to affect or change an employment relation because of union membership or actizitics." (Italics supplicd).

21. Bizarre interpretations of the Act indicate that the courts sometimes read generally rather than specifically. E.g., Union Premier Food Stores v. Retail Food Clcrlis, 
mand of the Act, is carefully to read its words in their context (italics are supplied, and the closed-shop proviso is omitted):

Section 8. It shall be an unfair labor practice for an employer:

(1) To interfere with, restrain, or coerce employees in the exercise of the rights guaranteed in Section 7.

(2) To dominate or interfere with the formation or administration of any labor organization or contribute financial or other support to it: ... [the grievance proviso follows].

(3) By discrimination in regard to hire or tenure of employment or any term or condition of employment to encourage or discourage membership in any labor organization: Provided, . . . [the closed shop proviso follows].

(4) To discharge or otherwise discriminate against an employee because he has filed or given testimony under this Act.

(5) To refuse to bargain collectively with the representatives of his employees, subject to the provisions of Section 9(a).

First, to meet the argument that there is no substantial difference between the way the Board interprets subsection (3) and the way Congress wrote it, subsection (4) is cogent proof that when Congress wanted to make "discrimination" because of a particular activity an unfair labor practice, it did so, in just those words. The same simple words were just as available for the structure of subsection (3). It could have been written as the Board interprets it, but it just wasn't. Why should it be assumed that Congress was aimlessly beating about the verbiage bush to make discrimination because of union activity an unfair practice in the face of such skillful straight-forward use of the apt words in a different connection in the next sentence ? $^{22}$

If Congress had meant to say what the Board says it meant, subsection (3) would have read: "To discriminate in regard to hire or tenure

98 F. (2d) 821 (C. C. A. 3d, 1938), in which the court amazingly misconstrued the Board's jurisdiction to depend upon the existence of a "labor dispute" as defined in $\$ 2(9)$, and then, more amazingly, misconstrued that definition to require a proximate relation of employer-employee, after quoting the words of the statute, which are cxactly the reverse. The district court, which had taken jurisdiction on the basis of a highly imaginative interpretation of $\S 10(\mathrm{e})$, decided that the Board had exclusive jurisdiction to direct an election to settle the question of representation, and thereupon helpiully appointed a special master to conduct an election under the Act. In N. L. R. R. v. Lion Shos Co., 97 F. (2d) 448 (C. C. A. 1st, 1938), the court surprisingly declared: "That the new union, when finally organized, constituted a unit for collective bargaining under $\$ 9$ (a) of the Act is clear." Mrost baffling of all is the court's order in Globe Cotton Mfills v. N.I.R.B., 4 L. R. R. 206 (C. C. A. 5th, 1939), overthrowing entirely the cease and desist portions of the Board's order, but enforcing that part granting affirmative relief. That the Board can order such relief only as supplementary to a cease and desist order is clear from the most hurried reading of $\$ 10(c)$.

22. See address by Chairman Madden before American Political Science Association, Columbus, O., Dec. 29, 1938: The Act is "a model of straight-forward statutory statement." 
of employment or any term or condition of employment because of labor organization membership or activities." One reason for the language actually used may well have been to avoid limiting, any more than necessary for the protection of the rights guaranteed in Section 7, what the House Report, ${ }^{23}$ the Board, ${ }^{24}$ and the Supreme Court ${ }^{25}$ have characterized as "the normal right of employers to select their employees or to discharge them." Another reason is protection of non-union minorities.

In each of subsections (1), (2), (4), and (5) the definition of the substantive unfair labor practice follows immediately the word "to"; that is, the conduct which is made the basis of liability for violation of the Act is described after the word "to" in four out of the five subsections. There is no reason to believe that that is not also true in the fifth case, that of subsection (3). The unfair labor practice under stubsection (3), then - the basis of liability - is for an employer "to encourage or discourage membership in a labor organization." The words preceding "to" in subsection (3) must be given effect, then, as a condition to liability, not as a basis of liability. In other words, "discrimination" is the proscribed means of encouragement or discouragement of membership in a labor organization, but the prohibited conduct is the encouragement or discouragement of membership. The fact that stibsection (3) was aimed particularly at the yellow-dog contract is highly significant in emphasizing the membership-protection aspect. Accordingly, the reports of the Senate ${ }^{26}$ and House ${ }^{27}$ Committees make it clear that the proper short statement of subsection (3) is that it "prohibits encouraging or discouraging membership in a labor organization by discrimination," and not, as the Board puts it, that it "prohibits discrimination because of union activity." 28 But after only one year of administration of the Act, the Board abandoned its original interpretation of the statutory provision ${ }^{29}$ and introduced an idea of its own. ${ }^{30}$ Despite the Board's difficulty in finding a satisfactory statement by which to relate its own views to the words of the Statute, we finally have the Board's word for it that the sole issue raised by an allegation of violation of Section $8(3)$ is whether the discharge involved was because of union activity. ${ }^{31}$ Surprisingly enough, this unexplained action of the Board has

23. Report of House Committee on LABOR, H. R. ReP. No. 1147, 74th Cong., 1st Sess. (1935) 19.

24. NLRB Third Annual Report (1939) 69.

25. See N. L. R. B. v. Jones \& Laughlin Steel Corp., 301 U. S. 1, $45-46$ (1937).

26. See Report of State Committee on Education and Lator, Sen, Rep. No, 573, 74th Cong., 1st Sess. (1935) 10, 11.

27. See Report of House Commitee on Labor, H. R. Rep. No. 1147, 74th Cong., 1st Sess. (1935) 19.

28. See In re Pennsylvania Greyhound Lines, Inc., 1 NLRB 1, 36 (1933).

29. NLRB First ANNUAL Report (1937) 77.

30. NLRB Second ANinual Report (1938) 69.

31. NLRB Third Annual Report (1939) 27 and (in slightly different words) 81. 
never been challenged by its many critics, nor, so far as appears, has the Board ever supported its interpretation by explicit reasoning. 22 Yet if it be argued that it makes no practical difference that the Board has brought conduct within subsection (3) which might not be within the actual words thereof, since the Board could surely bring anything which it characterizes as "discrimination" within the broad generalization of "interference" within Section $8(1)$, the answer is threefold:

First, that the same type of affirmative relief - back pay - may not be so matter-of-factly enforced by the courts. The Supreme Court has recently spoken portentously concerning the extent of the Board's power to order affirmative relief where a finding under subsection (1) was not reinforced by a finding of a specific unfair practice under one of the particular subdivisions: "The power to command affirmative action is remedial, not punitive . . "33 Certainly one effect of that decision, giving weight to the Court's stressing of the absence in the Board's decision of a finding of violation of Section $S(2)$, was to declare the Board powerless to order relief in connection with a finding of violation of Section 8(1) which would have been perfectly appropriate to a finding of violation of Section $8(2)$. Furthermore, although the power to order back pay is expressly granted, ${ }^{34}$ and is not specifically limited to remedy violations of Section $8(3)$, it is linked, perhaps inseparably, to reinstatement orders, and they seem, of course, to be most appropriate to remedy the only unfair practice which mentions tenure of employment. Second, that in any event, the Board has no authority to take any liberties whatsoever with the wording of the specific unfair labor practices, ${ }^{35}$ such as to read into Section $8(3)$ protection of union activities when membership alone is mentioned, nor to read into it the content of Section 7, if

32. See note 18 , supra.

33. N. L. R. B. v. Consolidated Edison Co., (1938) 6 U. S. L. WeEK 425, 429. In the Fansteel case, Justice Hughes, explaining and reinforcing the langugge of the Consolidated Edison case, declared: "We held that the authority to order affirmative action did not go so far as to confer a punitive jurisdiction ensbling the Beard to inflict upon the employer any penalty he may choose because he is engaged in uniair labor practices and the Board is of opinion that the policies of the Act may be effectuated by such an order." The Board's own policy is not to order back pay without a finding of violation of Section 8(3). This policy is almost universally present, but is seldom expressed; in two instances the Board has departed from it. In re Indianapolis Glove Co., 5 NLRB 231 (1938) ; In re Servel, Inc., 11 NLRB, No. 121 (1939). A more astute technique may obviate such departures in the future. In re Stehli \& Co., 11 NLRB, No. 124 (1939).

34. Section $10(\mathrm{~b})$.

35. See Report of Sexate Conmrtree on Enccition axo Lacor, Sex. Res. No. 573,74 th Cong., 1st Sess. (1935) : "The unfair labor practices . . . are strietly limited to those enumerated in Section 8. . . . Unlike the Federal Trade Commission Act - . this bill is specific in its terms. Neither the Board nor the Courts are giens any blanket authority to prohibit whatezer labor practices that in their judgnest are decmed unfair." Inclusion of the words "nor the Courts" repels the significance which might ordinarily attach to the courts' echoing of the Board's language. 
it be argued that that Section declares "rights" to union activities. Third, that such an interpretation has obscured, and eventually might result in terminating, the important function of Section 8(3) in protecting from oppression minorities within appropriate units.

Of course, no one would be fatuous enough to contend that discrimination because of union activities will not constitute a violation of Section 8(3) in, say, ninety-nine cases out of a hundred. But this is because such conduct by an employer ordinarily is purposed to discourage, and will also have the necessary effect of discouraging, membership in the union concerned. This explains, perhaps, why the Board for so long had a perfect record ${ }^{36}$ in the Supreme Court in cases in which the Board has found a violation of Section 8(3), and why the Supreme Court at first echoed the Board's language to the effect that Section 8(3) forbids discharges because of union activities. ${ }^{37}$ The point of the actual language of the Section has never been urged upon the Court, and the Court has no reason to presume that the Board, the body of experts charged with administration of the Act, has been torturing the statutory language. Much more significant than the language used is the fact that in every case won by the Board the union activities which had been the occasion of the discrimination were of the type the Court and all fair-minded persons would necessarily regard as legitimate union activities. When the union activities concerned consist of violence or illegal conduct, a different result follows, as the Fansteel case ${ }^{38}$ clearly establishes.

If it is possible to "discriminate because of union activities" without "encouraging or discouraging membership in a labor organization", it would seem to be the duty of the Board in each case of an allegation of violation of Section 8(3) to look for "substantial" evidence that the employer's conduct had the effect of such encouragement or discouragement. And the possibility of "discrimination" without "discouragement" is potential in both the type of union activities concerned and in the manner in which the discrimination is effected. That discouragement of union activities does not in all cases have the necessary effect of discouraging membership in the union in question will appear to anyone capable of imagining a union's engaging in activities, perhaps of a violent character, which would deter from joining conservative-minded employces who would otherwise join. But the Board decisions show numerous instances of types of union activities, even aside from violence, which, in the interest of maintaining order in the plant so that the work may go forward, could be made the basis for differentiation in treatment of

36. See note 6, supra.

37. Associated Press v. N. L. R. B., 301 U. S. 103 (1937).

38. The Fansteel opinion at 898-99 declares in effect that the Act protects only "lawful" union activities. 
the employees engaging in them without having the necessary effect of discouraging membership in the union concerned.

It became inevitable, as soon as the Board had firmly committed itself to the doctrine that union "activities" as well as membership were within the direct protection of Section 8(3), that the question would arise as to whether all types of union "activities" were so protected. Strange potentialities still dwell in this question. Bombings, dynamiting, and sabotage, may, at rare times, aptly be described as union "activities," as on the other hand, fatal machine-gunnings may properly be charged to employers. ${ }^{39}$ These types of activity and personal violence, trespass, technical trespass, and breach of contract are now established as without protection under the Act. But there may be a legitimate need for discharges for other reasons. This problem was not expressly settled by the Court's decisions of February 27, 1939. An evaluation of the Board's principal cases in this field is therefore indicated.

The Board's most explicit discussion of the problem occurs in In re Harnischfeger. ${ }^{40}$ In that case, the union, which represented a majority of the employees, decided to protest the refusal of the employer to sign a contract with the union by instructing the membership to work shorter shifts. As a result two shifts of employees were present in the plant at the same time causing "considerable confusion." The employer, thereupon, discharged all those responsible for having given the instructions, and contended that "their discharge was necessary if plant discipline was to be maintained."

But the claim of the employer was as futile as the Board's opinion is unenlightening. The Board declared first, that if the activity is designed to carry out a program of the union, it is a "union activity." Second, that Section 8(3), which nowhere mentions Section 7, embodies, somehow, all of that Section. Third, that it is not a violation of Section $8(3)$ to discharge for "any" (apparently used to mean "all types of") union activity. Fourth, that the Board must decide what types of union "activities" are protected by Section $8(3)$. The Board therefore is elaborating on its interpretation that "Section $S(3)$ prohibits discrimination because of union activity." It now adds, in effect, "but not all union activities: just those the Board may subsequently find not to be indefensible." Right here, perhaps, is the key, other than recognition of the need for protection of non-union minorities, to why Congress did not use the words which the Board uses in interpreting the enactment of Congress. As the Supreme Court accurately deduced in the Fansted case, Congress certainly was unwilling to restrict an employer to the extent of preventing discharge for any union activity of whatever type. How-

39. See, for example, the Board's colorful detective story included in its opinion in Iit re Republic Steel Corp., 9 NLRB, No. 33 (1938).

40. 9 NLRB, No. 64 (1938). 
ever, the alternative of restricting that term by the adjective "lawful" with its completely unpredictable content must have been recognized as courting destruction of the purposes of the Act in exactly the manner in which the Clayton Act"1 was destroyed as "Labor's Magna Charta" through use of that very word. It is not unsardonic that Mr. Justice Frankfurter had eloquently pictured the boomerang effects of such statutory restriction some ten years before he joined the Court just too late to participate in the decisions of February 27, 1939.42 The National Labor Relations Act is now laid open by those decisions. It may be that as an expert without peer in the field of labor legislation he would have shared the thought of Justices Reed ${ }^{43}$ and Black that the sit-down could have been just as eternally damned without carrying so substantial a part of the Act to Hades with it.

It may well be conceded that the Board has tried to stretch the protection of the Act too far, without at the same time agreeing that it was necessary for the Court to go equally far in the other direction and thus introduce potentially enormous confusion into administration of the Act. It is one purpose of this article to show that the Act itself definitely commands a middle course. For instance, it is plain from the Funsted group of cases that an employer may discharge for a "tort" or "breach of contract." 44 Introduction of such tests must perforce bring confusion, for the content of those terms is circumscribed only by the concept of law. A careful construction of the Act, however, would show that it actually avoids the difficulties presented on the one hand by an attempt to protect all types of union activities, and on the other by such completely non-functional and provenly untrustworthy tests as whether the employee action in question constituted a "tort" or a "breach of contract."

The Act furnishes its own criteria. These are new and functional. Section $8(3)$ directly protects only union membership; indirectly it pro-

41. 38 Stat. 738 (1914), 28 U. S. C. § 382 (1935).

42. Frankfurter and Greene, The Labor Injunction (1930) 144-146; 16\%-171. The language used by the Chief Justice in the Fanstecl case is strangely reminiscent of that quoted with obvious disapproval at $145 \mathrm{n}$. from an opinion by Pitncy, J., dissenting: from Justice Holmes' liberal interpretation of the Clayton Act's protection of Labor, in Paine Lumber Co. y. Neal, 244 U. S. 459, 484 (1917): "Neither in the language of the Section nor in the committee reports, is there an indication of a purpose to render lawful or legitimate anything that before the Act was unlawful, whether in the objccts of such an organization or its members or in the measures adopted for accomplishing them."

43. Justice Reed, who wrote the partially dissenting opinion, did not use those words, but he did declare that, "Disapproval of the sit-down does not logically compel the acceptance of the theory that an employer has the power to bar his striking employec from the protection of the Act." (1939) 6 U. S. L. WEEK 900.

44. "The Act does not prohibit an effective discharge for repudiation by the employce of his agreement any more than it prohibits such discharge for a tort committed against the employer." Roberts, J., citing the Fansteel opinion, in N. L. R. B. v. Sands Mfg. Co., (1939) 6 U. S. L. WEEK 887, 889. 
tects union activities only of such a character that the discharge of participants therein would "discourage membership in a labor organization." The criterion of Section $8(1)$ is slightly more complicated, since it proscribes "interference, restraint or coercion" of employ'ees in the exercise of the rights guaranteed in Section 7. That Section, then, is the only possible basis for affirmative protection of any kind of strilie. It provides:

"Employees shall have the right to self-organization, to form, join, or assist labor organizations, to bargain collectively through representatives of their own choosing, and to cngage in concertcd activities, for the purpose of collective bargaining or other mutual aid or protection." (Italics supplied).

The language "right . . . to engage in concerted activities" appears at first to include striking. A second reading reveals, however, that the Section protects in the line of union activities only orgastizational and defensive activities - concerted activities "for mutual aid or protection." The word "protection" should be enough to establish this, but the conclusion is reinforced by use of the word "other," which refers back to "collective bargaining." By familiar principles of statutory construction, therefore, "other" limits what follows to activities of the same general nature as collective bargaining. Collective bargaining is essentially peaceful - and industrial peace is the purpose of the Act. ${ }^{35}$ Sit-down striling, would, of course, be without the protection of the Act under this interpretation as a violent and, tactically speaking, offensize activity. If the Board had so construed the Act, the Chief Justice could have had no occasion in the course of argument of a case under the Act to ask such embarrassing questions as he did in the Fansted case, ${ }^{10}$ nor to write an opinion which may be seized upon to cripple the Act by lesser judges who have a congenital if perfectly honest distrust of organized labor.

The opinion in the Fansted case seems to assume that a "lawful" strike is within the affirmative protection of the Act. The question does not appear to be that easy. It may be that there is confusion between protecting striking - as the Board has done, for example, by holding that conduct of an employer in deliberately frightening peaceful pickets into giving up picketing constitutes a violation of the Act - and protecting former

45. Declaration of policy in $\$ 1$ of NLRB, supra note $1 ;$ N. L. R. B. v. Consolidated Edison Co., (1938) 6 U. S. L. WEEK 425.

46. In the course of the Government's argument in the Fansted case, MIr. Fahy, General Counsel of the Board, was asked the following question by the Chicf Justice: "Suppose a striking employee met his employer on the street and assaulted him, and suppose the employer had strength enough to say, 'I discharge you,' would the Board have the power to order his reinstatement?" (1939) 6 U. S. L. WeEr 620. In Bennett-Hubbard Candy Co., 11 NLRB, No. 97 (1939) the employer actually was clubbed over the head-by a person unknown-during a strike attended by "considerable violence" and not caused by any unfair labor practice. The Board ordered the striliers reinstated, with back pay from the time some were refused reinstatement. 
participants in a strike when applying for reinstatement, as the Supreme Court did in the Mackay case. ${ }^{47}$ True it is that Section 13 expressly provides that: "Nothing in this Act shall be construed so as to interfere with or impede or diminish in any way the right to strike," but such language, although highly emphatic, is entirely neutral as to augmenting such a right. In any event, although the Court was clearly right in holding that a sit-down strike is not within whatever protection is extended by Section 13, the words used by the Court in the particular connection were unfortunate: "This recognition of the 'right' to strike plainly contemplates a lawful strike - the exercise of the unquestioned right to quit work." ${ }^{48}$ This might introduce into the administration of the Act all of the confusion of the common labor law as to what constitutes a "lawful" strike and the ends for which men may strike. ${ }^{40}$ Local law might prevail by reason of Erie Railroad $v$. Tampkins. ${ }^{\text {co }}$ It would have been more in conformity with the Act to say that if it protects any striking activity at all, such protection is limited to a strike for "mutual aid or protection."

But assuming that an ordinary strike is a "concerted activity," as is declared by Section 7 to be a right of employees, the courts refuse to construe even Section $8(1)$ as affording complete protection to it. Hiring strike-breakers, or, to avoid use of a term with such a connotation of force, new employees during a strike, certainly seems the most effective way possible to interfere with a strike. Yet the employer's absolute right to hire such persons during a strike is enunciated in the Mackay case. The strike in that case was not caused by an unfair labor practice, but even in cases where such cause is found to exist, the employer still may hire new employees to take the place of strikers. ${ }^{51}$

Sound policy underlies the Board's contention that it must protect union officials under Section 8(3). It is unfortunate that the Board's best explanation of this appears in In re Shell Petroleum Corporation. ${ }^{62}$ which involved a sit-down strike. The grievance committee of a stiblocal union which was holding employer property during a sit-down strike refused to permit employer officials accompanied by officers of the parent local to approach the strikers to explain to them the new working schedules in protest of which the strike had been called. The employer discharged the three members of the committee because of this action, claiming that they were responsible for maintenance of the strike and

47. N. L. R. B. v. Mackay Radio \& Tel. Co., 304 U. S. 333 (1938).

48. N. L. R. B. v. Fansteel Corp., (1939) 6 U. S. L. WeEK 896.

49. FRANKFURTER AND GReENE, op. cit. suipra note 42, at 1-43.

50. 304 U. S. 96 (1938).

51. N. L. R. B. v. Mackay Radio \& Tel. Co., 304 U. S. 333 (1938) ; Black Diamond Steamship Corp. v. N. L. R. B., 94 F. (2d) 875 (C. C. A. 2d, 1938) ; N. L. R. B. v. Remington Rand, Inc., 94 F. (2d) 862 (C. C. A. 2d, 1938).

52. 10 NLRB, No. 60 (1938). 
the continued holding of the property. The Board held that the discharges were in violation of Section 8(3), explaining:

"For if union representatives are made to assume the risk of personal responsibility for the actions of their union, no employee of the employer will be willing to accept the position of representative." ${ }^{3} 3$

The argument fails in the case in which it is enunciated, of course, since there it rests on the never reasonably tenable and now completely destroyed assumption that sit-down striking is a union activity affirmatively protected by the Act. It should make excellent sense, however, in any case in which the strike was non-violent or not in breach of a contract.

A typical example of a perfectly legitimate union "activity" which could not be the occasion for discrimination without a resulting discouragement of membership in the union concerned is found in the KellySpringfield Tire Company case. ${ }^{\sigma 4}$ The discharged employee was chairman of the union grievance committee in his department. The employer characterized the employee's activity as "amateur detective work and snooping around and gathering complaints." In this situation the same result would be reached by application of any interpretation of Section $8(3)$. The Court would hold that the employee was within the protection of the Act, since his activity was "lawful." Application of the theory herein advanced would show a discouragement of union membership by the discrimination through depriving members of legitimate and defensive benefits of such membership - representation in presentation of grierances. The Board held that the discharge was in violation of the Section simply because the activity was a union activity. ${ }^{50}$

Resort by an employer to promulgating in advance regulations proscribing union activities will not necessarily solve his problems of discipline. The Board has never denied an employer's right to make such rules and regulations, and it professes not to "attempt to interpret employers' rules or pass upon their reasonableness,"

53. Id. at 11 .

54. 6 NLRB 325 (1938), consent decree, Kelly-Springfield Tire Co. v. N. L. R. B., 97 F. (2d) 1007 (C. C. A. 4th, 1938).

55. Id. at 331 .

56. In re Montgomery Ward and Co., 4 NLRB 1151, 1156 (1938). But $f$. In re American MIfg. Concern, 7 NLRB 753, 760 (1938). "The fact that the respondent sought to justify its action by promulgating a plant rule does not alter our conclusion, since an employer cannot, in the name of a plant rule, coerce his employees for the purpose of discouraging collective activity."

In the Botany Worsted Mills case, 4 NLRB 292, 300 (1937), the Bo3rd concluded that Peidl's discharge was in violation of Section $8(3)$ of the Act, although it conceded that the alleged rule prohibiting outside activities during working hours was in itself unobjectionable and within the company's lawful power to adopt and discharge. But 
not the Board's decisions have been to the effect that, in the case of a particular discharge, the purported resort to enforcement of the regulations was "merely a pretext to conceal the anti-union motive for the discharge." The same technique could be used by the Board if rules were incorporated into a "contract" in an attempt to rely upon the language of the Sands case.

Turning from employers' problems of discipline and the types of union activities which could be made the basis of discriminatory treatment without necessarily having the effect of discouraging union membership, to possible methods of discrimination which could be used without necessarily discouraging union membership, the Board's cases show that it flatly denies the possibility of any such methods. The Board has long adhered to the position that it is immaterial whether or not just cause for discharge exists if the discharge is even partly motivated by antiunion bias. ${ }^{57}$ This goes much farther, of course, than the Board's familiar doctrine that the mere existence of just cause is no justification for a discharge. ${ }^{58}$ That doctrine is obviously properly applicable wherever the discharge in question discouraged union membership and the existing proper reason for discharge was merely an afterthought ${ }^{50}$ or even at one hundred per cent pretext. But where there "are two or more reasons" and only one of them is union affiliation or activity, and the Board, without considering evidence as to whether the discharge did discourage union membership or activity, holds it in violation of Section $8(3)$, with concomitant liability for reinstatement and back pay, it seems entircly too much like punishing an employer for anti-union thoughts. It may be doubted that Congress intended to reach that far. The manner or method of the discrimination in these cases almost assures that there will be no effect of discouragement of union membership. There exists a perfectly good and publicized reason for the discharge; it is given out to the employee directly concerned and to his fellows. The secret antiunion part of the motive is known only to the employer - for the particular reason that he does not want to incur liability under the Act. But

in In re Midland Steel Products Co., 11 NLRB, No. 112 (1939), the Board declared: "We have grave doubts that the solicitation of union members on an employer's property on his own time is subject to lawful prohibition by an employer."

57. NLRB Third Annual Report (1939) 70.

58. Discharge of an employee because of union activity may constitute discrimination within $\S 8(3)$ regardless of "proper causes" for discharge then existing. In $r c$ ISellySpringfield Tire Co., 6 NLRB 325, 342 (1938) ; In re Arcade Sunshine Co., 12 NLRB (1939). Cf. In re Wald Transfer Co., 3 NLRB 712 (1937) (failure of an employer to reinstate union leaders while restraining other union members after walkout for reasons not connected with any union purpose held a violation of $\$ 8(3)$ - even though employer was justified in replacing immediately with outsiders all employees who walked out).

59. The Board frequently and soundly rejects as justification any reason for a discharge discovered only after the event. These attempts are characterized as "afterthoughts". For example, In re Empire Furniture Corp., 10 NLRB, No. 92 (1939). 
assume that the Board finds it out on cross-examination at a hearing. The Board will find a violation of Section $8(3)$. It is true that in such cases there is an intent, but it is an intent to discriminate, not an intent to discourage union membership, and there is no discouragement in fact. Thus the Board under this doctrine not only makes an anti-union-activities motive in connection with a discharge an extra-statutory basis of liability under Section $8(3)$, but makes also any motive other than a one hundred per cent non-anti-union motive similarly a basis for liability. ${ }^{60}$

One further interpretation which may be viewed as stretching too far in one direction the unfair labor practice under Section $8(3)$ should be explored before turning to that unique function of the Section which, far from being stretched at all, has never yet been involied. The Board, if it ever has occasion, may say that it is not necessary that an employer's discriminatory conduct be successful in discouraging union membership in order to constitute an unfair labor practice under Section $S(3)$. The Board has held that an employer's conduct with respect to a labor organization need not be successful in bringing into being a dominated labor organization, ${ }^{61}$ or, indeed, have any effect at all, ${ }^{62}$ in order to constitute an unfair practice under Section $8(2)$. With equal assurance the Board has held that a showing of a concurrent cause operating independently toward the same end as conduct of an employer is no defense to a charge of interference, "since it is an unfair labor practice within the meaning of Section 8(1) for an employer to interfere with the rights of his employees guaranteed in Section 7 irrespective of the success of such interference." ${ }^{3}$

But merely because that theory fits nicely subsections (1) and (2) of Section 8 is no indication that it may be applied to subsections (3) and (5). Both subsections (1) and (2) prohibit specifically the "successful" conduct which the Statute seeks to eliminate, and then in effect add, "or attempts at such conduct" by introducing "interference" as an alternative basis of liability. In subsection (1) the words "restrain" and "coerce" each carry the connotation of something accomplished; and "interfere with" is an added precaution against attempts to restrain or coerce. Section $8(2)$ seeks to abolish company-dominated unions as a recognized obstacle to collective bargaining, so it uses the word "dominate," and adds as a safeguard against attempts at such domination the alternative "or interfere with." But it would be absurd to suppose that Section 8(5) makes it an unfair labor practice unsuccessfully to attempt to refuse to bargain collectively. So it is with Section $8(3)$. The result

60. See note 57 , supra.

61. In re Millfay Mfg. Co., 2 NLRB 919 (1937); see In re Canvas Glove Mig. Co., 1 NLRB 519, 526 (1936).

62. In re Emsco Derrick Co., 11 NLRB, No. 17 (1939).

63. In re Yale \& Towne Affg. Co., 10 NLRB, No. 116 (1939). 
there sought to be abolished was discouragement or encouragement of membership in any labor organization. An unsuccessful intermeddling may amount to interference, but a discouragement that fails of any discouraging effect is, by definition, not discouragement. It might amount to "interference," but Congress significantly left any such word out of Section 8(3). The strictest interpretation of Section $8(3)$ would, of course, require not only proof that membership in a union was in fact encouraged or discouraged, but also a specific intent to bring about that result. Such an intent could not be shown by substantial evidence in the union activities-employer discipline cases considered above. ${ }^{\mathbf{6 4}}$

The Unused Function of Protection of Non-Union Minoritics. The perhaps sorely needed but as yet uninvoked protection afforded non-union minorities is found in Section 8(3)'s proscription of encouragement by an employer of membership in any labor organization. Most significant is the failure to make any exception for the benefit of majority unions except as to closed shop contracts. ${ }^{65}$ If, therefore, Section $8(3)$ is properly invoked and properly construed, only by securing a closed shop contract can a union deny to non-union minorities the fruits of collective bargaining. To illustrate, if a majority union, by reason of its superior economic power and favored position under the Act, has overcome an employer's resistance to any type of contract other than one containing a closed shop clause, and has secured an agreement requiring, for members only, wage increases, minimum guaranties, or vacations, is it an unfair labor practice for the employer to fail to grant similar concessions to non-union employees, even though the contract purports to restrict them to union members? Obviously the answer is yes. Section $8(3)$ by clear terms permits an employer to encourage membership in any union by discrimination in regard to hire, or tentre of employment or any term or condition of employment, only indirectly by making an agreement with a labor organization which is the free and uncoerced representative of the majority of employees "to require as a condition of employment membership therein," and in no other way whatsoever. And a contract either more than or less than a closed shop contract is no justification, nor does it matter that the union concerned is a bona fide majority union. The problem is important because it is highly probable that many contracts now in effect secure special favors for union mem-

64. Discussed supra pp. 1158 et seq.

65. The closed-shop proviso appended to the substantive provision of $\S 8(3)$ reads : "Provided that nothing in this Act ... shall preclude an employer from making an agreement with a labor organization (not established, maintained, or assisted by any action defined in this Act as an unfair labor practice) to require as a condition of $\mathrm{cm}$ ployment membership therein, if such labor organization is the representative of the employees as provided in Section 9 (a) in the appropriate collective bargaining unit covered by such agreement when made." 
bers. ${ }^{66}$ In such a situation, although the Board has never mentioned it, ${ }^{\text {,T }}$ the non-union employees are clearly entitled to file charges of violation of Section 8(3), and the Board, to maintain a consistent position with its remedies in discouragement cases, would have to order differential back pay if union members had been receiving higher wages for the same work. More frequently the Board would have to order accrued vacations or overtime-off, since those are typical advantages which unions attempt by contract to corner for union members.

Section 8(5) makes it an unfair labor practice for an employer "to refuse to bargain collectively with the representatives of his employees, subject to the provisions of Section 9(a)."

Section 9 (a) provides:

"Representatives designated . . . by the majority ... shall be the exclusive representatives of all the employees . . . for the purposes of collective bargaining."

Thus Section 9(a) confers upon the majority union power to bargain for all of the employees. But no one can compel ${ }^{63}$ the union to exercise this power: that is the gist of the problem. For an employer to refuse to bargain with a majority union for its members only does not, however, appear to be an unfair labor practice. The employer's duty under Section $8(5)$ is made subject to the provisions of Section $9(a)$. That Section provides that the majority union "shall be the exclusiz'e representatives of all the employees." So, if the majority union refuses to proceed under Section $9(\mathrm{a})$, one of the conditions to the existence of the employer's duty under Section $8(5)$ is not met. Therefore an employer can, if the Act is so construed, refuse with legal impunity to enter into any negotiations at all concerning a members-only contract, even with a majority union.

Recent Board decisions foreshadow a situation in which not only unaffiliated employees but also members of a majority union at a particular plant of a large company may need the protection against negotiation of discriminatory contracts which is found only in Section $8(3)$. The Board is showing an increasing tendency toward finding that all plants of large manufacturing companies together constitute a single unit appropriate for collective bargaining. ${ }^{09}$ This has been true even though

66. A recent representation case before the Board, for example, involved a contract denying seniority privileges to non-members. In re Reading Transportation Co., 10 NLRB, No. 2 (1938).

67. The Board is under no duty to do so. If it did, unions would not be pleased at losing one of their best membership campaign arguments.

68. The Board has devised at least one persuader: it will reduce an exclusive representation contract to the status of a contract for members only. See note 66, sufro.

69. In re Pittsburgh Plate Glass Co., $10 \mathrm{NLRB}$, No. 102 (1939); In re LibbeyOwens-Ford Glass Co., 10 NLRB, No. 134 (1939); a similar situation may exist where the Board has found that a multi-employer unit is appropriate, and many plants are 
the plants are hundreds of miles apart and are operated independently of each other. ${ }^{70}$ The Board holds that it does not matter that all or practically all of the employees at one plant ${ }^{71}$ belong to one union and desire a separate unit if a rival union has organized the majority of the employees in all the plants considered as a single unit. The Board's theory is excellent. Undoubtedly, granting the desire of the employces in the one plant for a separate unit would prevent presentation of a united front in collective negotiations with the employer and thus "inevitably hamper and obstruct the far larger number of the company's employces at the other plants in their efforts to organize and bargain collectively." "7 The employees at such a single plant may, however, be glad to find in Section 8(3) protection from oppressive bargaining by the rival union, which, by the Board's decision, is now made their exclusive representative.

In sharp contrast to the complete absence of any Board decisions applying Section $8(3)$ to protect minorities in any of the three situations discussed above, is the wealth of cases wherein the Board has invoked the Section to protect members of one of two rival unions in a single plant. $^{73}$ The Board's position in such cases is thoroughly sound. The true statutory basis of liability is applied, with the explanation: "The employer's act of favoritism toward either union necessarily encourages membership in the favored union and discourages membership in the disfavored union." 74 Thus Section 8(3) may, if involied, function to protect minorities from oppression at the hands of majority unions. ${ }^{76}$ But it also may serve to protect unaffiliated employees caught in the everunenviable position of the innocent bystander. A surprisingly recurrent situation has been that in which an employer has shut down a plant or a department in order to lock out union members or to discourage unionization. Where the Board finds those facts, it orders back pay for the complainant unionists. ${ }^{76}$ Are non-union men employed in the same plant

solidly affiliated with a union which does not have a majority of all the employees in all of the plants of all of the employers covered into the unit. The Board has had a number of such cases: In re Admiar Rubber Co., 9 NLRB, No. 35 (1938); In re Hyman-Michaels Co., 11 NLRB, No. 60 (1939).

70. In re Pittsburgh Plate Glass Co., 10 NLRB, No. 102 (1939).

71. About 1300 out of 1600 in the Pittsburgh Plate Glass Co. case and 133 out of 134 in the Libbey-Owens-Ford Glass Co. case.

72. In re Pittsburgh Plate Glass Co., 10 NLRB, No. 102 (1939); similar langunge is used in the Libbey-Owens-Ford case; all of which seems somewhat inconsistent with the Board's famous Globe doctrine of self-determination of homogeneous groups. In re Globe Machine and Stamping Co., 3 NLRB 294 (1937).

73. Cases cited NLRB Third ANnual Report (1939) $68 \mathrm{n}$.

74. NLRB Third ANnual Report (1939) 68.

75. This might well be pointed out as negativing the need for proposed amendments to protect coercion from "any source," since it takes care of the most pressing of the alleged needs in this line.

76. In re National Motor Bearing Co., 5 NLRB 409 (1938); In re Ford A. Smith, 1 NLRB 950 (1936). 
or department, who also were deprived of their wages by the same conduct of the employer, to get nothing? That has been the answer thus far. ${ }^{77}$ The Board has proceeded on the theory that it could not enter any order affecting the status of employees not named in the complaint, and, since in each case it has been the union which filed the charges, only union members have been named in the complaint. This reasoning of the Board is highly inconsistent with the position it takes in awarding relief to union members not named in the complaint and to non-union strikers. The Board does not declare itself helpless in those cases. ${ }^{78}$ In at least one case involving the right of a non-striking, non-member of a union to relief in a lock-out situation, the Board seems to have ignored the Act entirely. ${ }^{79}$ Certainly there is nothing in the Act which commands employees to engage in "union activities," or deprives them of rights under the Act if they fail to do so. Consequently, whenerer the Board holds that a shut-down constitutes a lock-out in violation of Section 8(3), non-union employees should be entitled to the same remedies, including reinstatement and back pay, as those ordered for the union members. As the Circuit Court of Appeals for the Ninth Circuit has accurately stated:

"There is nothing in the Act which limits the reinstatement remedy to members of labor organizations or cuen to striking cmployecs who are primarily and dircctly aggricucd by an unfair labor praclice auhich causes a strike." 80 (Italics supplied).

The words of the court indicate a clear understanding that the Act can and should be administered to protect the non-union, non-striking "innocent bystander" employees caught in a cross-fire between employer and union.

77. It may be that the Board has included non-union employees in bacl: pay orders in this situation (it always includes non-union as well as union strikers if a striks is involved), but if so the writer has not been able to discover it. The order in Is re Somerset Shoe Company, 5 NLRB 486, 495 (1938), sounds as if it did, since it decrees bacls pay for "all employees who were laid off by reason of the shut-down on Miarch 24, 1937." However, that case was decided the very day following the decision in In re National Motor Bcaring case, 5 NLRB 409 (1938), and there is no indieation in the opinion of any change in the Board's nolicy in this resnect. It may be that the term "all employees" referred to all union employees, or to all union employees named in the complaint, or it may have happened that all the employees were union membsrs.

78. In re Shellabarger Grain Products Co., \& NLRB 336 (1938) (reinstating union members not named in complaint); In re Biles-Coleman Lumber Co., 4 SLRB 679 (1937) (reinstating strikers who were not members of the union), eniorced in N. L. R. B. v. Biles-Coleman Lumber Co., 98 F. (2d) is (C. C. A. 9th, 1939).

79. See In re Kuehne Mfg. Co., 7 NLRB 304, 323 (1938) (employee in effest penalized for not participating in a sit-down strike).

S0. N. L. R. B. v. Biles-Coleman Lumber Co., 96 F. (2d) 197 (C. C. A. 9th, 193S), 98 F. (2d) 18 (C. C. A. 9th, 1938). 


\section{Principles Enunciated in Decisions under Section 8(3)}

"Discrimination" as A term of ART. Because "discrimination" is generally treated by the Board as the basis of liability under Section $8(3)$, and because the exact words of the Section make it at least an essential condition of liability thereunder, the Board's working definition of "discrimination," as enunciated in its decisions, is of great practical moment. Especially is this true because the Board has made the word into a term of art with a content surprisingly wider than ordinary. Lay and legal definitions generally agree that "to discriminate" means "to make a difference or distinction in treatment." 81 Thus two elements seem to be of the essence - differentiation, and affirmative action in the making thereof. But neither of these is regarded by the Board as a necessary ingredient of discrimination within the Board's interpretation of Section 8(3). The three types of cases which raise the question happen to be among the most important, from a financial viewpoint, of all the types of cases handled by the Board, since they generally involve large groups of employees rather than individuals. In cases of one of these types the Board finds a violation of Section 8(3), although no difference is made in the treatment of union members and non-union employees. In cases of the second type, "discrimination" is found, although the employer's conduct is, in the strictest view, a nonfeasance. In cases of the third type, all of a class of employees are held to be victims of discrimination because of action against several of their number.

(1) "Discrimination" zerithout a difference. The situation characterized by the Board as a "mass discharge" throws most brilliantly into relief the delineation of discrimination without differentiation. In the early case of Ford A. Smith, ${ }^{82}$ the Board held that the closing of a partially organized plant, purportedly because of rising costs of production, "must be regarded as a mass discharge aimed solely at those among them who favored the Union." But the plant's closing took effect on non-union employees as well. In In re National Motor Bearing Com-

81. Webster's New International Dictionary (Merriam Series). Prior to the Act, court cases defining "discrimination" generally dealt with common carriers, at common law or under federal statutes. Most of them stressed the element of difference in treatment, e.g., "The word 'discriminate' may be defined as treating one differently from another." Wimberly v. Georgia So. \& F. Ry. Co., 5 Ga. App. 263, 266, 63 S. E. 29, 31 (1908). "'Discrimination' means to make a difference between . . ." Wynn v. Wabash R. Co., 111 Mo. App. 642, 648, 86 S. W. 562, 563 (1905). Litigation of collective batrgaining contracts has brought the term before the courts in a setting somewhat similar to its use in the Act: e.g., in Cross Mountain Coal Co. v. Ault, 157 Tenn. 461, 9 S. W. (2d) 692 (1928) (refusal to permit discharged employee to return to work solely because he was an officer of a labor union was held to constitute "discrimination" as used in contract). In such cases, however, "discrimination" is the forbidden conduct, whereas in the Act it is encouraging or discouraging membership in unions which is proscribed.

82. 1 NLRB 950 (1936). 
pany, ${ }^{83}$ the management claimed that the plant had been shut down because of an alarming drop in the rate of production and because of rumors that a sit-down strike was imminent. The opinion of the Board pointed out the absence of differentiation between union and non-union workers, but nevertheless found a violation of Section $8(3)$ in that the lockout was aimed at the union. ${ }^{84}$

(2) "Discrimination" by nonfeasance. Frequently the Board has held that an employer, whose unfair labor practices have caused a strike, has been guilty of discrimination by failure or refusal to displace new employees $^{85}$ to provide positions for the replacement of strikers immediately upon their request. ${ }^{80}$ The Board is well backed by court authority for this type of ruling, particularly the Black Diamond Steamship case. ${ }^{87}$ The Board explains in greater detail elsewhere that failure to displace new employees "in effect and in result" discriminates in regard to hire and tenure of employment against striking employees and in favor of employees "whose position was one of sufferance, without greater right to their positions than their employer's defeasible right to employ them could afford." ${ }^{88}$ Such a discrimination, the Board concludes, discourages union membership.

(3) "Discrimination" taking effect aicariously. Under ordinary and conventional meanings of the term "discrimination," no one could be heard to say that someone had discriminated against him by unfavorable action against a third party. Yet the Board has held that an employer "discriminated" against all of his striking employees by permitting a committee of "loyal" employees to refuse the reinstatement of strikers who had been active on the picket line while permitting the reinstatement of

83. 5 NLRB 409 (1938).

84. A similar result was reached by the Board in In re Somerset Shoe Co., 5 NLRB 486, 491 (1938) and in In re Patriarchia Store Fixtures, Inc, 12 N.L.R.B., No. 11 (1939).

85. "New employees" include also persons formerly but not recently employed by" the employer who were last hired after the strike. In to Acme Air Appliance Co., 10 NLRB, No. 123 (1939).

86. In re IIcKaig-Hatch, Inc, 10 NLRB, No. 4 (1939); In re Western Felt llorls, 10 NLRB, No. 31 (1939); In re Denver Automobile Dealers Ass'n, el al., 10 NLRB, No. 108 (1939); In re Bennett-Hubbard Candy Co., 11 NLRB, No. 97 (1939). In re Trenton Garment Co., 4 NLRB 1186 (1938). In In re General Shoe Corp., 5 NLRB 1005 (1938), the Board held that the employer's inaction in the face of activities of "bouncer squads" of inside union adherents in ousting outside union members from the plant constituted a "delegation of authority" to the "bouncer squads," in vicw of its "affirmative duty to protect its employees during working hours and to maintain safe working places for them." An additional type of discrimination by non-feasance is created in In re Asheville Hosiery Co., 11 NLRB, No. 122 (1939), holding that an employer's failure to protect union employees against an anti-union faction "amounts to a discrimination in regard to a term or condition of employment", in violation of Section $8(3)$.

87. Black Diamond S. S. Corp. v. N. L. R. B., 94 F. (2d) 875 (C. C. A. 2J, 1938).

88. In re MicKaig-Hatch, Inc., 10 NLRB, No. 4 (1939). 
"neutral" strikers who had not taken part in such activities. ${ }^{80}$ Although the Board may find sound basis in the Act for its rulings in the cases discussed in paragraphs (1) and (2) above, this third departure seems to be an unjustified stretching of the definition. Differentiating action does not constitute discrimination against an employee unless it impinges upon his individual rights under the Act. There is no question in this type of case that the strike leaders are discriminated against (under the Court's decisions, justifiably so if there has been violence or technical trespass) by refusing to reinstate them, but as to other strikers who are offered reinstatement, the most that could be said is that there has been a violation of Section $8(1)$.

TyPes of Discriarinatory CONDUCT. "Most commonly the employer's act of discrimination," the Board explains, "consists in outright discharge, either individually or in groups." 90 But a wide variety of other discriminatory acts are included also in the sweeping words of the Section, "discrimination in regard to hire or tenure of employment or any term or condition of employment." Thus the Board includes lay-off, refusal to reinstate, demotion, transfer, and refusal to employ, among the other classifications of frequent conduct which, when coupled with anti-union motivation, constitutes discrimination. ${ }^{91}$

(1) "Discharges" during strikes. A fine distinction of financial importance is drawn by the Board in cases involving alleged discriminatory discharges in the course of strikes. The situation at first seems enormously confused by apparently cryptic utterances of the Board, sometimes that the employer really doesn't mean it when he says "All strikers atre hereby discharged," even if he has his attorney say it for him; and other times that an employer has "discharged" all of the strikers although he has not said so. The distinction, the Board explains, ${ }^{02}$ is between mere "tactics" and an "effective discharge." Unfortunately for the sake of easy clarification, the term "effective discharge" is not nearly so accurate as it sounds. Chief among the Board's articles of faith, and well supported by the Court's decision in the Mackay case, is that the definition of "employee" in Section 2(2) of the Act renders an employer powerless to destroy "employee status" during a strike. ${ }^{03}$ The Fanstecl opinion

S9. In re Sunshine Mining Co., 7 NLRB 1252, 1269 (1938).

90. NLRB ThIRd ANNuAL Report (1939) 72.

91. Ibid. Difficulty arises however in the question whether the action by the employer "did or did not effectuate or constitute a change in an employment relationship."

92. Id. at 76-77. The Board abandoned this theory of a "tactical" but not "actural" discharge in the course of the argument before the Stupreme Court in the Fanstecl case, but probably did so for the purposes of that argument and that case only.

93. The Board's position is most succinctly stated at NLRB ThIRv ANNuAL Rurolr (1939) 77n.: "Whether the employer's purported discharge or purported refusal to reinstate is mere 'tactical step' or a gemine declaration, it can have no effect on the enployee's status as conferred upon the employee by Section 2(3) of the Act." Cited as 
quotes with fine approval language of the Mackay case to that effect, and so the Fansteel doctrine will affect necessarily only cases wherein the strikes involved are not "lawful." Sit-downs were a dying vogue many months past and appear finally to be smothered by the weight of the Chief Justice's words and the economic penalties resulting from loss of rights under the Act. ${ }^{94}$ However, other varieties of strikes have always provided the really wide area for application of the Board's doctrine of the "tactical" strike. Board statistics showed" a markedly increasing tendency of unions to resort to procedure under the Act, instead of trying a strike first, as enforcement of the Act became effective following the Court's decisions of April, 1937. This tendency probably will reverse when enforcement bogs down with the wider and more frequent court review which will result from the psychological effects of the Fansteel, Sands, and Columbian cases and the first application of the new evidence sufficiency tests to the Board's findings of fact. ${ }^{00}$ The Board will doubtless persist in applying the doctrine that a discharge is not effective wherever an employer purports to discharge strikers who have not engaged in violence or broken a contract. The prime reason for the doctrine is, of course, to preserve the Board's power to order reinstatement.

In some cases, however, the doctrine of the "tactical" discharge has quite another function. The symmetry of the Board's decisions requires back pay orders in all cases of discriminatory discharge, yet a mass order for back pay would be impolitic in many situations. On the other hand, the Board is so shocked at some types of employer conduct in the course of strikes that it may wish temporarily to lay aside the doctrine that "employee status" cannot be destroyed within such a period, so that back pay may be ordered as a fitting remedy. Since the distinction between the "tactical" and the "effective" discharge is more imaginary than real

direct authority for this is N. L. R. B. v. Carlisle Lumber Co., 94 F. (2d) 138 (C. C. A. 9th, 1937), cert. denied, 304 U. S. 575 (1938).

The Board takes the further view that the Act entitles strikers to a reasonable assurance of reemployment, and that to threaten them with discharge is a violation of $\$ 8(1)$. In re Acme Air Appliance Co., 10 NLRB, No. 123 (1939).

94. The only major sit-down recently in progress terminated immediately upan announcement of the Fanstel opinion (Bendix Corporation plant at South Bend, Ind.) (1939) 4 L. R. R. 3. Also an employer in Newark immediately announced to strikers whose sit-down had recently terminated that they were diselzarged. The union asserted that it would ignore this as a mere incident in the strike, thus showing labor's pressure for a distinction between "tactical" and "real" discharges such as the Board maintains. The legal penalties for sit-downs are drastic. Ark v. Fansteel Afetallurgical Corp., 295 IIl. App. 323 (1938), cert. denied, (1939) 6 U. S. L. Weer 853; Apex Hosiery Co. v. Leader, E. D. Pa, Apr. 24, 1939, 4 L. R. R. 320.

95. NLRB Third ANNual Report (1939) 1.

96. Ward, Proof of Discrimination under the National Labor Relations Act (May, 1939) 7 Geo. Wash. L. Rev. 
because of the indestructibility of status doctrine, this distinction lends itself easily to manipulation one way or the other depending whether or not the Board wishes to lay a foundation for a back pay order. A comparison of cases reaching opposite results shows the Board's doctrines in action. ${ }^{97}$ Although, on one hand, the discharge "in name only" has appeared harmless to the employer charged under a Section 8(3) complaint, $^{, 8}$ on the other hand the Board's contrarywise decisions growing out of such discharge are of great financial and strategic importance to employers, employees, and unions. ${ }^{00}$

The vacillating character of the Board's decisions on this point is shown by the reasoning in In re Stackpole Carbon Company. had been given checks marked "paid in full" and were told that they would never get back in the plant, but the Board declared:

"The complaint alleges that the respondent discharged its striking employees. The facts . . . do not sustain the allegation. After ceasing work the position of the respondent's striking employees was, from a practical point of view, unaffected by the acts complained of. Since they had already ceased their work, there is no question of discriminatory discharge; the question arises only as to whether there was a discriminatory refusal to reinstate them to their former employment." (Italics supplied). ${ }^{101}$

That case seems to be out of line, however, and a discriminatory mass discharge of strikers has been found in several cases. This results in the anomalous, or at least unique, holding that strikers not shown to be willing to resume work are entitled to back pay. (Ordinarily the Board carefully avoids reaching such a result, holding, for instance, that employees on strike because of the employer's unfair labor practices may not condition a request for reinstatement such as will entitle them to back pay on the employer's ceasing such unfair practices). ${ }^{102}$ Signing during a strike by an employer of a closed shop contract with a rival union having no majority in the plant is also treated by the Board as

97. But no sit-down cases will be considered since that field is closed to the doctrine by the Fansteel decision.

98. In re Biles Lumber Co., 4 NLRB 679 (1937), cnforced in N. L. R. B. v. Biles Lumber Co., 96 F. (2d) 197, (C. C. A. 9th, 1938), 98 F. (2d) 18 (C. C. A. 9th, 1938), and Board rejected the contention that there was a discriminatory discharge within $\S 8(3)$, and held that it was "only a threat" and had been so construed by the strikers. In re American Mff. Concern, 7 NLRB 753 (1938) the Section 8(3) complaint was dismissed on the ground that the discharge was not real but merely tactical.

99. See NLRB Third AnNual Report (1939) 77-78.

100. 6 NLRB 171 (1938).

101. Id. at 198 .

102. In re Fansteel Corp., 5 NLRB 930 (1938), enforcement denied on other grounds in N. L. R. B. v. Fansteel Metallurgical Corp., (1939) 6 U. S. L. WeEK 896; this type of ruling is discussed infra p. 1177. 
a mass discharge of all strikers, and back pay may be ordered to run from the date of the signing of the contract. ${ }^{103}$

(2) General content of term "discharge." When a strike is not current, no difficulty is presented in cases turning on the obvious types of discharge, from the formal notification on a blue slip, to the crisp "you're fired" of an authorized foreman. In this situation the Board never denies face value to affirmative words of discharge, as it sometimes does if similar words are used during a strike. Where a discriminatory discharge is complained of, a "discharge" must be proved, so neither mere threats of discharge nor an unreasonable belief by an employee that he has been discharged will be sufficient to support such a complaint. ${ }^{104}$ But in addition to the out-and-out or obvious type of discharge, the Board recognizes a number of different types of constructive discharge. Thus, an employer "precipitating an emotional crisis making it impossible for the girls to continue working," "constructively" and discriminatorily discharged them, within Section 8(3), although they quit their work under such compulsions. ${ }^{105} \mathrm{~A}$ demotion inducing a resignation is also held to be equivalent to a discharge if the demotion was made because of union activities. ${ }^{106}$ Similar results are reached by the Board in cases in which it appears that an employee has been coerced into quitting ${ }^{10 i}$ by transfer or other discriminatory treatment. ${ }^{108}$

103. 7 NLRB 304 (1938), summarized at NLRB TuIRd Axzual Reroms (1939) 77. In re Jacob A. Hunkele, 7 NLRB 1276 (1938); of. In re TVilliams Coal Co., ct al. (case of Grapevine Coal Co.), 11 NLRB, No. 49 (1939), the Board held that effectuating the closed shop agreement subsequent to the strike was equivalent to a refusal at that time of an application by the striking employees for reinstatement (although they in fact made no application), and such "refusal" to reinstate was a "discharge" which could be the basis for back pay from that date. Cf. In re Shellabarger Grain Products Corp., 8 NLRB 336 (1938), in which back pay was ordered to run from the date of imposition of a condition of reemployment of strikers which "had the effect of denying striking employees employment if and when they ceased striking."

104. Employees who were threatened with discharge were not justificd in considering themselves discharged. In re Trenton Garment Co., 4 NLRB 1186, 1192 (1933). However, it does not matter that an employee may liase been mistalien in his belief that he had been discharged, if the employer intended to create an impression that he would be discharged because of his union membership, and the employer "tscitly acquiesced" in the employee's understanding that he had been discharged. In re Planters Mfig. Co., 10 NLRB, No. 61 (1938). The general problem is discussed at NLRB Tnusp Ax:uns REPORT (1939) 74.

105. In re Sterling Corset Co., Inc., 9 NLRB, No. 79 (1938).

106. In re Waggoner Co., 6 NLRB 731 (1938), NLRB Tump Ar:aval Reront (1939) 75.

107. NLRB Third Annual Report (1939) 75, cases n. 38.

108. The defense of the employer that the employee "voluntarily quit" is not very" effective. In re Yale \& Towne MIfg. Co., 10 NLRB, No. 116 (1939). In Mrount Fernon Car Co., 11 NLRB, No. 46 (1939), the Board held that the action of employecs in demanding the amount of their pay ordinarily held back in the case of current employees did not constitute voluntary termination of employment, where prior to their action they had been wrongfully refused employment. 
An important type of constructive discharge ${ }^{100}$ was defined by the Board in In re Atlas Mills: 110 "To condition employment upon the abandonment by the employees of the rights guaranteed them by the $\Lambda$ ct is equivalent to discharging them outright for union activities." Perhaps this is irrefutable as a principle of administration of the Act (assuming "union activities" to be of the type the discouragement of which necessarily discourages union membership) but the occasion for its enunciation may not be the most opportune one possible.

Another type of discharge might more appropriately be tagged "vicarious" than "constructive," since it may be explained under familiar principles of the law of agency. The Board holds the employer responsible as for a discharge whenever the employment relation is terminated against the will of the employee by action "attributable to" the etr1ployer. ${ }^{111}$ It is no defense for an employer to contend that the action interrupting the employment was not taken by anyone with authority to hire and fire, if such action was taken: pursuant to a closed shop contract with a union assisted by any unfair labor practice; ;12 by unorganized employees purportedly refusing to work with members of an outside union, if this attitude was encouraged by the employer ;113 by "bouncer squads" of inside union members, if adequate police protection was available but was not sought by the employer ${ }^{114}$ or, in general, if the employer knows of the occurrence and "does nothing to rectify the situation." 115 Obviously the employer is vicariously liable for discliarge if he has delegated authority to anti-union agencies of any sort. ${ }^{110}$

109. Several other very important types of constructive discharge are discussed infra p. 1177 , in connection with the subject of "Content of 'failure to reinstate" ", particularly under the point of when a request for reinstatement is not necessary. Cf. discussion of holding in In re Williams Coal Co., 11 NLRB, No. 49 (1939).

110. 3 NLRB 10,17 (1937). Each employee left after being asked "whether they wanted to remain with the company or go out on strike." But a much more appropriate occasion for the enunciation of such a principle was presented in In re Louisville Refining Co., 4 NLRB 844 (1938). The Board held as a violation of $\S 8(3)$ the employer's notification to the employee that he could not use him until he decided not to go out on strike if called upon by the organizer.

111. NLRB Third ANNual Report (1939) 74.

112. In re The Grace Co., 7 NLRB 766 (1939), summarized in NLRB Tumb ANNUAL REPORT (1939) 74.

113. In re Clover Fork Coal Co., 4 NLRB 202, enforecd in Clover Fork Coal Co. v. N. L. R. B., 97 F. (2d) 331 (C. C. A. 6th, 1938).

114. In re General Shoe Corp., 5 NLRB 1005 (1938).

115. NLRB Third Annual Report (1939) 74; see discussion "Discrimination by nonfeasance", supra p. 1171.

116. In re Shellabarger Grain Products Corp., 8 NLRB 336 (1938); In re Frederick R. Barrett, 3 NLRB 513 (1937). NLRB Third Annus Report (1939) 69: "Highzway Trailer Company illustrates another method of discrimination. The cmployer agreed to discharge any employee whom the company-dominated union deemed undesirable. A discharge pursuant to the direction of this union was found to be in violation of the Section. The Board has reached the same result where the favored union, al- 
(3) Content of "failure to rcinstate." 11 A discriminatory rejection of an application for reinstatement after a non-discriminatory lay-off or a strike is, in the Board's view, obviously a violation of Section 8(3). If that were the totality of the content of "failure to reinstate," a complete analysis could be made by determining merely what constitutes an application for reinstatement and what constitutes a rejection thereof. The general rule, however, is not that "no infraction arises until the employee induces employer action by making application for reinstatement," but merely the much less inflexible rule that "ordinarily no infraction arises" until application is made. ${ }^{118}$ For the Board holds that "under some circumstances an application for reinstatement is not prerequisite to finding a refusal to reinstate in violation of Section 8(3)." 110 Those circumstances also must be examined, therefore, because of their financial and tactical importance.

An application for reinstatement may be made individually or collectively, ${ }^{120}$ and no particular formula need be used. The most that is required in the way of form is, in some cases, that the request be "clearcut." 121 But it may not be conditional. ${ }^{122}$ Complications arise from the Board's nice distinction that it may be "coupled with" but cannot be "conditioned on" union demands, even if the demands go no further than that the employer accord to the employees rights guaranteed them by the Act. In re Fansteel Metallurgical Corporation ${ }^{123}$ clearly established

though not company-dominated, was assisted by other unfair labor practices, and where the favored union was not otherwise assisted by uniair labor practices."

117. In connection with this type of employer conduct also the Roard regards "discrimination" as the basis of liability under the Section, and construes the Section to give direct protection to all types of union "activities", regardless of whether or not they are types of activity the restriction of which by the employer would necessarily result in discouragement of union membership.

11S. NLRB ThIRD AxNeal Report (1939) 7s.

119. Id. at 79.

120. In re Alabama Mills, Inc, 2 NLRB 20 (1936); cf. In re IFilliams Coal Co., 11 NLRB, No. 49 (1939): "There is no evidence that any employees, other than these (four), personally, through the U.A.IY.A., or otherwise, made or sought to malse application for reinstatement"; held, there was no refusal to reinstate.

121. In re Fansteel Corp., 5 NLRB 930 (1938), cuforcement denicd on olher grounds, N. L. R. B. v. Fansteel Corp., (1939) 6 U. S. L. WeEk 896.

122. Strikers may not condition their application for reinstatement upon a demand that the employer cease from committing, or remedy, unfair labor practices. The rationale of this line of decisions is that if an employer engages in uniair lator practices, the employees have their choice of protesting by a strike or seeking the remedy provided by the Act, but they cannot expect to strike and also to get back pay under the Act. Sce notes 136 and 137, infra. Cf. matter of Sunshine Co., 7 NLRE 1252 (1938).

123. The Board's decision in the Fanstecl case, 5 NLRE 930, 945 (1938), stated the Board's consistent doctrine on this point: "It might be argued that since the Union was demanding as a condition to reinstatement only something to which they were entitled under the Act-recognition and collective hargaining-the respondent in illegally refusing this demand should be considered as discriminatorily refusing to reinstate the strilsers. 
the proposition that an employer cannot be said to have refused reinstatement to strikers so long as they were unwilling to return to work under conditions existing at the time the strike was called, even though the strikers were demanding as a condition of reinstatement only the union recognition and collective bargaining to which they were entitled under the Act. The Board feels so strongly that a conditional request for reinstatement is no basis for a finding of violation of Section 8(3) that in In re Hemp \& Company, ${ }^{124}$ the Board conditioned its reinstatement order in favor of employees found to have been discriminatorily locked out, upon an application by them for reinstatement, although ordinarily no such request is required of victims of discrimination, where they had taken the position at the hearing that they would not accept an offer of reinstatement unless the employer would recognize as their bargaining representative the union which represented a majority of the employees. However, in In re Black Diannond Steamship Corporation, ${ }^{125}$ the union asked the employer to reinstate all strikers and to bargain with the union (which had been certified by the Board as the exclusive bar. gaining representative). The employer refused reinstatement and the Board held that the refusal subsequent to the union's request constituted a violation of Section 8(3): "The respondent can find no refuge in the fact that the application for reinstatement may have been coupled with demands for collective bargaining."

The only other important requisite of an application is that it must be timely. No discriminatory refusal to reinstate is found in cases where the refusal occurs in response to a request made too early, that is, at a time when the employer's plant has not resumed full capacity operations, ${ }^{120}$ nor if the request is made too late, ${ }^{\mathbf{1 2 7}}$ after all positions have been filled in a non-discriminatory manner upon termination of a strike. ${ }^{128}$ Once the employee has induced employer action by a sufficient application for reinstatement, the next element to be tested for sufficiency is the employer's response thereto. Of course, if the employee goes back to work, the matter is settled. If, however, the employer makes what he contends is an offer of reinstatement, but which the employee does not choose

We do not take this view. So long as the employees were unwilling to return to work under the conditions existing at the time the strike was called, however just the grounds on which their position was based, it cannot be said that the respondent was refusing to reinstate them."

124. 9 NLRB, No. 41 (1938).

125. 3 NLRB 84, summarized at NLRB ThIRD AwnunL RepoRT (1939) 79, order enforced, Black Diamond S. S. Corp. v. N. L. R. B., 94 F. (2d) 875 (C. C. A. 2d, 1936), cert. denied, 304 U. S. 333 (1938).

126. See In re Phillips Packing Co., 5 NLRB 272, 282 (1938).

127. See In re Carrollton Metal Products Co., 6 NLRB 569, 586 (1938) (case of Frank Morrell).

128. In re Sigmund Freisinger, 10 NLRB, No. 93 (1939). 
to accept, the offer must meet three tests established by the Board's decisions before the Board will give it the effect of preventing the accrual of back pay and the necessity of another offer of reinstatement. It must be made in good faith; the employment offered must be "substantially equivalent" to that held before the interruption by strike or lay-off; and the offer may not be conditioned on the employee's giving up any rights guaranteed by the Act.

Typical of an offer not made in good faith is that involved in In re West Kentucky Coal Company ${ }^{129}$ wherein the employee was offered and refused a job which would have been difficult for him to perform because of his age. Numerous Board opinions define what is not "substantially equivalent employment." Reinstatement of strikers "as if they were newly employed" is not equivalent, since they are entitled to "their seniority and other rights and privileges." 130 Nor is it sufficient to offer a job paying the same hourly wage as before the strike where an interim general wage increase had been granted. ${ }^{131}$ Reinstatement at a plant sixty miles away from the place of the former employment "falls short of substantially equivalent employment." 132 Rather difficult to classify is the deficiency found by the Board to exist in the offer of reinstatement made by the employer during the hearing in In re General Shoe Corporation ${ }^{123}$ to outside union employees found by the Board to have been discriminatorily discharged in that they had been evicted from the plant by members of an inside union. The Board held that the offer was not "an unqualified offer" and therefore did not interrupt the running of back pay, since it did not "guarantee them the full protection at their employment which every employer normally owes to his employees." The third requirement of a sufficient offer - that it be not conditioned on giving up rights under the Act - is obvious, and what constitutes such a condition may best be discussed in connection with the next following subject of when a request for reinstatement is not necessary.

129. 10 NLRB, No. 10 (1939).

130. In re Western Felt Works, 10 NLRB, No. 31 (1938).

131. Ibid. If, however, no general interim wage increase has been granted, a reiusal to accept an offer of reinstatement because of dissatisfaction with a reduction in the wage scale just prior to the strike, precluded a finding of discriminatory reiusal to reinstate. See In re Pioneer Pearl Button Co., 1 NLRB 837, S43 (1936); NLRB SECO:id ANNUAL REPORT (1938) 77.

132. In re Kuehne Alfg. Co., 7 NLRB 304 (1938). Apparently an offer of employment at one of the employer's plants only four miles distant is not equivalent, even though it is exactly the same kind of work, where the employee concerned is a key figure in the union's organizing campaign in the plant of his original cmployment. In re Nekoosa-Edwards Paper Co., 11 NLRB, No. 42 (1939).

133. See note 114, supra. The Board explains elsewhere that "The ofier of reinstatement must be unequivocal, else the Board will not consider it bona fide." NLRB TnIsD AnNual Report (1939) 80. 
The Board holds that an application for reinstatement is not prerequisite to finding a refusal to reinstate ${ }^{134}$ in violation of Section $8(3)$, for two widely divergent reasons: when an application is reasonably believed to be unnecessary, and when it would reasonably be thought to be futile. The first reason exists, for example, where the employer's former policy has been to notify laid-off employees when they werc to resume work, ${ }^{135}$ or where the employer has announced, in connection with a lay-off, that the employees would be notified when to return. ${ }^{130}$

The question of when the second reason for dispensing with the necessity of an application for reinstatement exists is instilled with actute financial interest. The Board's $\$ 200,000$ back pay order in In re Carlislc Lumber Company ${ }^{137}$ arose out of such a situation. "Typically," the Board explains, "the discriminatory action rendering an application unnecessary is an offer of reinstatement by the employer based upon an unlawful condition. . . . In several cases the unlawful condition of reinstatement imposed by the employer provides for renunciation of an employeropposed union, the notorious 'yellow-dog' contract." ${ }^{138}$ 'The Carlislc Lumber case ${ }^{130}$ involved a situation wherein a strike had been called, and the employer had notified all strikers that they were clischarged, before the effective date of the Act. About three weeks after the $\Lambda$ ct became effective, the employer posted a notice stating that it would hire on pre-strike terms all former employees who would sign application cards. By the terms of the application cards, the signer agreed "to renounce any and all affiliation with any labor organization." Most of the union members made no application for reinstatement, but the Board nevertheless found a discriminatory refusal to reinstate, reasoning that they should not be penalized for not making an application which they knew would be fruitless. Publishing the notice relieved the strikers "of the necessity of making a formal application; nor is it an answer to say that they were striking and would not have applied in any cvent: that was for them to decide." The same reasoning applies in cases where the employer requires as a condition of reemployment execution of in-

134. An application for reinstatement is never required for a finding of violation of $\$ 8(3)$ in the case of dischargcs, including mass discharges or lock-outs. NLRB SxcowD Annual Report (1938) 76 and cases n. 33 thereto; In re L. C. Smith and Corona Typewriter Co., 11 NLRB, No. 123 (1939).

135. NLRB Third ANival Report (1939) 79; In re Waterman Steamship Cotp, 7 NLRB 237 (1939).

136. In $r c$ North Whittier Heights Citrus Ass'n, 10 NLRB, No. 113 (1939); In re Western Felt Works, 10 NLRB, No. 108 (1939).

137. 2 NLRB 248 (1936), order enforced, N. L. R. B. v. Carlisle Lumber Co, $941 \%$ (2d) 138 (C. C. A. 9th, 1937), cert. denied, 304 U. S. 575 (1938), further litigated 9n $\mathrm{F}$. (2d) 533 (C. C. A. 9th, 1938), cert. denicd, (1939) 6 U. S. L. WeEK 914.

138. NLRB Third Axincal Rerort (1939).80; see In re Western Felt Worlis, 10 NLRB, No. 108 (1939).

139. See note 137 , supra. 
dividual contracts in derogation of any rights guaranteed by the Act, even though they do not forbid union membership. ${ }^{240}$ The Board has held that requiring signature of contracts depriving employees of "the right to demand recognition by the employer of any union" - the original Balleisen type of contract"141 - or depriving them of "right to demand a closed shop or signed agreement by the employer with any union" 142 - the modified type of Balleisen contract - constitutes a violation of Section 8(3).

Attaching to reinstatement the condition of joining a union favored by the employer by means of a closed shop contract or otherwise, not only relieves strikers of the necessity of applying for work, ${ }^{143}$ but is treated as a constructive discharge. ${ }^{14}$ Blacklisting certain employees or omitting them from lists approved for reemployment has the same result, and if such action induced certain strikers to delay making applications for reinstatement, the employer cannot rely upon a "first come, first served" explanation to negative discrimination against union leaders. The Board has the support of the Supreme Court on this. ${ }^{145}$ Another situa-

140. In re Newark Rivet Works, 9 NLRB, No. 47 (1938); of. In re Atlas Bag and Burlap Co., 1 NLRB 292 (1936).

141. In re Atlas Bag and Burlap Co., 1 NLRB 292 (1936).

142. In re Federal Carton Corp., 5 NLRB 879 (1938). The same result follows if the individual contracts required to be signed were purportedly the result of collective negotiations between the employer and a union found to be employer-dominated within \$ 8(2). In re Newark Rivet Works, 9 NLRB, No. 47 (1938). Balleisen has played the part of the "heavy" in many Board decisions, but the Circuit Court of Appeals for the Second Circuit refuses to let the Board order employers to cease using his services "for the purposes of evading their obligations under the Act". N. L. R. B. v. Hopwood Retinning Co., Inc., 98 F. (2d) 97 (C. C. A. 2d, 1938). The order would seem to be proper in view of its restriction as to purpose.

143. In re Jacob A. Hunkele, 7 NLRB 304 (1938); In re The Grace Co., 7 NLRB 766 (1939); NLRB Third ANNual Report (1939) 80. The Board refers to this as the "erection of an illegal barrier against reemployment", and points out this relieves the employees from the "necessity of making formal application for vork:" "Similarly," the Board adds, "an employer who violates Section 8(3) does not interrupt the continuance of the unfair labor practice by making an offer of reinstatement . . . which is qualified by the unlawful condition of their joining an employer-favored union. The Board has held that failure to make application pursuant to such a discriminatory offer is immaterial; even though the employees might not have responded to an offer not so conditioned."

144. The reasoning given in support of treating such conditions as constituting constructive discharge is most fully set forth in In re Williams Coal Co., 11 NLRB, NYo. 49 (1939) : "Such condition (a closed shop contract found not within the protection of the proviso clause to Section $8(3)$ was imposed subsequent to the strike by the respondent. Its imposition on June 16 was equivalent to a refusal by the respondent at that time of an application by the striking employees to be reinstated for failure to conform to the condition. It is immaterial that the employees in fact made no application for reinstatement. Since the respondent at no time prior to June 16 terminated the employment of the employees on strike, its refusal (the constructive refusal) to reinstate was a discharge of these employees."

145. See note 47 , supra. 
tion regarded by the Board as rendering it futile for strikers to apply, and hence relieving them of the necessity, is shown in a case wherein the employer had delegated to an anti-outside-union committee authority to decide which, if any, strikers should be reinstated, and the committee had denied the applications of two strikers and indicated to the remainder that applications would be useless. ${ }^{146}$

(4) Discrimination by conduct not affecting hire or temurc. Matching perspicacity against ingenuity, the Board has condemned as "discrimination in regard to . . . any term or condition of employment" several varieties of conduct generally more subtle than that which affects hire or tenure. A fine question arises as to just how trivial discrimination as to conditions of employment must be before the Board will ignore it. When the differentiation in treatment resulted merely in conditions being "not so pleasant" as those previously enjoyed, the complaint was found not to be sustained. Calling due money owed the employer by two employees who had gone on a sympathy strike was likewise insufficient. ${ }^{147}$ And when a pressman's foreman who knew of his union activities supplied him with "short" rolls and kept his press rolling faster than those tended by other employees, so that the union man either was not ready with his rolls or "had to work hard" to keep up the pace, the Board "considered that treatment to constitute discrimination of so minor a nature as not to warrant a finding that the respondent discriminated within the meaning of the Act."148

Coal mines seem to provide the best locales for anti-union employers seeking to vent a little spleen against union members by making their work difficult. In In re Harlan Fuel Company, ${ }^{148}$ union employees were transferred to working rooms of "insufficient size," or else were not supplied with "sufficient equipment," and thus prevented from earning as much as they would have under normal working conditions. A thoughtful employer in another case assigned union men to stations where they would have to move so much rock and dirt that they would be working from weeks to months with no compensation for coal produced. ${ }^{\text {1ro }}$ By the same token, any transfer to set the stage for a future discharge or lay-off of a particularly active union member on purported grounds of inefficiency or low seniority in the new department, or to force him to

146. In re Shellabarger Grain Products Corp., 8 NLRB 336 (1938).

It is extremely difficult to predict the circumstances in which the Board will atpply its "futility of application" doctrine. See the opinion in In re Williams Coal Co., 11 NLRB, No. 49 (1939).

147. In re G. Sommers \& Co., 5 NLRB 992 (1938).

148. In re A. S. Abell Co., 5 NLRB 644 (1938); cf. In re Matter of Washington Mfg. Co., 4 NLRB 970 (1938).

149. 8 NLRB 25 (1938).

150. In re Clover Fork Coal Co., 4 NLRB 202 (1937), order enforced, Clover Fork Coal Co. v. N. L. R. B., 97 F. (2d) 331 (C. C. A. 6th, 1938). 
quit, will be considered discrimination. ${ }^{151}$ But, to be discriminatory, a transfer need not involve decreased wages or more difficult work. The skilled mechanic is a proud man and does not take kindly to being removed from responsibility. The Board's decisions recognize this. ${ }^{102}$ Nevertheless, placing union men in less desirable jobs does not of itself establish discrimination. Following a strike two union men were reinstated to "less desirable" jobs, and the union complained of discrimination against its members "in the time and manner of reinstating them." The Board dismissed the complaint, declaring that its analysis of jobs held before and after the strike showed that "within a reasonable time after the strike two men had been given better jobs, five men were doing work comparable to their pre-strike occupations, while only two men had less desirable jobs."153 Withholding a wage increase or other benefits from employees who have not joined a favored union or signed individual contracts purportedly negotiated by an employer-dominated labor organization is an obvious but surprisingly common type of discrimination. ${ }^{254}$

Persons protected by Section 8(3). The Section does not expressly state who is within its protection. From use of the words "lire or tenure of employment," however, the implication is clear that two great classes of persons are protected: (1) applicants for employment, and (2) employees.

(1) The Board has explained that it is not essential to a finding of an unfair practice under the Section that the status of employee be held by the person against whom the discrimination has been directed, "for the provision thereof has express application to a discrimination as to hire. And where the charge of discrimination does relate to hire, the fact that an employee status has not existed is wholly without probative bearing on the issue whether an unlawful discrimination has occurred." 155

151. In re Pulaski Veneer Corp., 10 NLRB, No. 11 (1938); In re Cincinnati Malling Co., 9 NLRB, No. 40 (1938) (order withdrawn, Feb. 10, 1938); In re lekoosa-Edwards Paper Co., 11 NLRB, No. 42 (1939).

152. In In re Douglas Aircraft Co., 10 NLRB, No. 18 (1938), an employee was found to have been the victim of discrimination by virtue of a transfer which made no difierence in his pay, but deprived him of responsibilities; in a case involving stilled cmployees of an electric utility company, the Board declared that "topmen" vere humiliated by being put to work in the "poleyard", and being seen there by their fellow employees.

153. In re United States Smelting, Refining and Mining Co., 10 NLRB, No. 91 (1939).

154. In re Federal Carton Corp., 5 NLRB 879 (1938) (15 per cent wage increase); Iis re Mit. Vernon Car Co., 11 NLRB, No. 46 (1939) (seniority provision disfavoring employees who were not members of union on particular date). A coercively-imposed check-off arrangement is held to constitute a discriminatory condition of employment. In re Williams Coal Co., 11 NLRB, No. 49 (1939).

155. In re Kelly-Springfield Tire Co., 6 NLRB 325 (1938), consent decree of chforcement, $97 \mathrm{~F}$. (2d) 1007 (C. C. A. 4th, 1938). The decision was also grounded on a finding that the respondent has "assumed" the relationship of employer to the persons concerned. 
In In re Montgomery Ward and Company, ${ }^{150}$ the Board squarely held that refusing employment, because of his union membership, to a per'son who had never been employed by the company, constituted an unfair practice within the Section. The rationale, according to the Board, is that protection of prospective employees is necessary for the protection of present employees, because anti-union discrimination against an applicant is as effective a means for communicating to employees the employer's campaign against the union as discrimination against a present employee. ${ }^{157}$ As early as June, 1936, the Board was using the Section as a basis for back pay orders in favor of one-time employees who had been "discriminatorily" discharged (no labor dispute resulting) months prior to the effective date of the Act and who were found to have been discriminatorily refused employment shortly after the Act took effect. ${ }^{150}$ The back pay was, of course, computed from the refusal to employ. The "imaginary horrible" of sweeping back pay orclers in favor of applicants for employment who might be believed by the Board to have been discriminatorily refused employment has never materialized, however. In no case has the Board ordered back pay for an applicant who had never been employed by the respondent employer or the predecessor in interest thereof. The remedy for such persons is placement on a preferential employment list. ${ }^{160}$

(2) Typically, the Board explains, discrimination is against an employee. Thus used, however, "employee" is a term of art, with potentialities of inclusiveness far outrunning those of that much litigated word in its general legal usage. In the first place, the Statute itself has injected new content by declaring the inclusion of "any individual whose work has ceased as a consequence of, or in connection with, any current labor dispute or because of any unfair labor practice." 161 Secondly, the Board seems likely to override the most pervasive limitation of the term. Say "employee" to any lawyer and one of his first thoughts is "someone not an independent contractor or employed by an independent contractor."

156. 4 NLRB 1151 (1938).

157. NLRB Third ANNuAl Report (1939) 73.

158. A labor dispute, if still "current", could have preserved their status as "en1ployees" under the Act, even though it commenced prior to the effective date of the Act. N. L. R. B. v. Carlisle Lumber Co., 94 F. (2d) 138 (C. C. A. 9th, 1937), ccrt. denict, 304 U. S. 575 (1938).

159. In re National Casket Co., Inc., 1 NLRB 963 (1936). A former employee who had voluntarily resigned is also within the protection of the Section and entitled to back pay if discriminatorily refused employment. In re Cherry Cotton Mills, 4 NLRB 731 (1937), opinion withdrazm and reissucd, 11 NLRB, No. 44 (1939).

160. In re Montgomery Ward and Co., 4 NLRB 1151 (1938).

161. Section 2(3). Most of the argument in the Fansted and related cases concerned the effect of this definition. The Court declared in its opinion that there is abundint opportunity for operation of this definition in situations similar to that of the Maclay case (a non-violent strike) "without construing it as countenancing lawlessness." 
Not so the Board. Taking a well-founded functional approach, the Board has defined the term to include "all employees in the conventional as well as legal sense," declaring that "the primary consideration is whether effectuation of the declared policy and purposes of the Act comprehends securing to the individual the rights guaranteed and the protection afforded by the Act." 162 The significance of the definition lies in the fact that from it the Board reasons that contracts, although carefully framed to create the status of independent contractor, are not conclusive, since "public interest in the administration of the Act permits an inquiry into the material facts and substance of the relationship." 103 Thus the Board has laid the basis for bringing within the protection of Section 8(3) many classes of persons ordinarily considered as independent contractors but who, for practical purposes, are economic dependents of the respondent employer.

All classes of employees are within the protection of the Section regardless of their managerial or supervisory status ${ }^{204}$ or high wages or salaries. ${ }^{165}$ Employees erroneously supposed by the employer to be union members or active in a union have been protected by the Board in many cases. An opinion explains: "that the respondent was mistaken and selected the wrong man makes the discharge no less a discrimination."166 Unaffiliated employees who are relatives of active union members are entitled to relief under the Section if their discharges were even

162. In re Seattle Post-Intelligencer Dep't, 9 NLRB, No. 119 (1938). Although this was a representation case under $\$ 9(\mathrm{c})$, the Board later applied the doctrine in a complaint case In re Interstate Granite Corp., 11 NLRB, No. 89 (1939). The definition has also been approved and applied again in a more recent representation case, In re Connor Land and Lumber Co., 11 NLRB, No. 58 (1939).

163. Ibid.

164. NLRB ThiRd ANNuAl Report (1939) 67. "The Board has found the cmployer's anti-union discrimination an unfair labor practice, regardless of the status of the employee. In In re Fruehauf Trailer Company, [1 NLRB CS (1935), order cuforecd, N. L. R. B. v. Fruehauf Trailer Co., 301 U. S. 49 (1937)] the Board found that an unfair labor practice had occurred with respect to a subforeman who had been discharged for union activity. A similar result was reached involving a foreman, newspaper circulation district and branch managers, and a power house chief engineer." See also In re Atlantic Greyhound Corp., 7 NLRB 1189 (1938). Contra: In re Kuchne MIfg. Co., 7 NLRB 304 (1938). However, in N. L. R. B. v. Biles Coleman Lumber Co., 96 F. (2d) 197 (C. C. A. 9th, 1938); id., 98 F. (2d) 18 (C. C. A. 9th, 1938), the company contested the Board's power to order reinstatement of non-union workers who had gone on the strike, particularly two foremen, and the court specifically held that $\$ \S 10(c)$ and $2(3)$ conferred such power on the Board.

165. In In re Metro-Goldwyn-Mayer Studios, et al., 7 NLRB 662 (1938), a representation case, the Board rejected the argument that the Act was intended to protect only wage earners in the lower income brackets and hence does not apply to creative and professional workers paid as much as $\$ 2,000$ a week:

166. In re Hamilton Brown Shoe Co., 9 NLRB, No. 99 (1938), and see NLRB TninD ANNUAL REPORT (1939) 76 and cases, n. 76. 
"indirectly" caused by discrimination against union members. ${ }^{107}$ Former members of defunct unions are held to be protected by the Section. ${ }^{108}$ And prospective members of potential unions are accorded the same protection. ${ }^{169}$ The nearest the Board has ever come to recognizing that the Section protects purely non-union employees who have never struck or even been suspected of membership or collective activities is the statement in the Third Annual Report that "the employer's anti-union discrimination has on occasions been directed even to those not suspected of union activity." 170 The only case cited, however, is In re National Motor Bearing Company, ${ }^{171}$ and although that is cautiously preceded by a $c f$. signal, the Report does not add that the non-union employees affected by the discrimination were accorded no remedy by the Board's Decision and Order.

Strikers (whether union members or not) are broadly protected by Section $8(3)$ in accordance with the Board's unequivocal rationale that the Act "imposes on employers the same duty not to discriminate in regard to strikers as exists with respect to employees still working and not participating in the strike." 172 Potential strikers also are protected ${ }^{173}$ and strikers who refuse an offer to return to work during a strike. ${ }^{174}$ Sit-down strikers and those who aid them are, of course, no longer within the protection of the Act since the Fansteel decision. Probably excluded also by that decision are participants in any "unlawf tul" strike.175 And the Sands case strips the protection from any employee who "re-

167. In re Memphis Furniture Mfg. Co., 3 NLRB 26 (1937), order enforcd, Memphis Furniture Co. v. N. L. R. B., 96 F. (2d) 1018 (C. C. A. 6th, 1938) ; In re Mansfield Mills, 3 NLRB 901 (1937); cf. In re Fashion Piece Dye Works, 6 NLIRB 274 (1938) (discharge of non-union employee held discriminatory, within $\$ \&(3)$, where employer alleged as reason fear that he would commit sabotage because his brother, an active union member, had been discharged).

168. In re Appalachian Electric Power Co., 3 NLRB 240 (1937), cnforcement denicd on other grounds, Appalachian Electric Power Co. v. N. L. R. B., 93 F. (2d) 985 (C. C. A. 4th, 1938).

169. In re Stehli \& Co., 11 NLRB, No. 124 (1934); see NLRB THIRD ANNuAL REPORT (1939) 68.

170. NLRB Third Annuat. Report (1939) 67.

171. Discussed supra p. 1170.

172. In re Shellabarger Grain Products Corp., 8 NLRB 336 (1938). In the case of a non-violent strike, this view is strongly supported by the Supreme Court's opinion in the Mackay case. Removal of watchmen from their duties during a strike because they were too sympathetic with the strikers' cause was held by the Board not to constitute an unfair practice within $\S 8(3)$. In re United States Stamping Co., 5 NLRB 172 (1938).

173. In re Louisville Refining Co., 4 NLRB 844 (1938).

174. "To permit the employer to discriminate against strikers when they alply for reinstatement merely because they had previously refused an offer to work, is, of course, a deliberate rebuke to concerted action by members of a labor organization." Sce In rc Sunshine Hosiery Co., 1 NLRB 664, 673 (1936).

175. See (1939) 6 U. S. L. WEEK $896,899$. 
pudiates his agreement."176 The scope of this exclusion is presently unpredictable, since the Sands case, although it involved a collective agreement, may prove to be an even greater incentive to the multiplication of "contracts" of a subtly anti-union nature than the case of Hilchman Coal \& Coke Co. v. Mitchell ${ }^{17 \pi}$ was to multiplication of blatant yellowdog contracts. ${ }^{178}$

Persons vicariously LIAbLe For Discriarination. Familiar problems of application of the doctrine of respondeat superior and "disregard" of corporate entities take on no special color under the Act. They constantly arise, however, particularly in connection with allegedly unauthorized action by foremen and other supervisory employees. ${ }^{270}$ One of the Board's most continuously repeated principles is that action by supervisors, with whom the employees are in closest contact and to whom they look for indication of the employer's attitude, is of far greater significance in determining unfair labor practices than the words of high officials. ${ }^{130}$ Of course, if the Supreme Court actually meant what Justice Roberts seems to have said in the Sands case ${ }^{181}$ - that a plant superintendent does not "hold such a position that his statements are evidence of the company's policy" - then the Board's entire doctrine on this point has been shattered to bits by the Court's quiet dynamite. If those words were intended, typical future evidence of a company's anti-union bias will be found only in formal resolutions condemning unions, duly passed by the board of directors.

Defenses to complaints of Discrimination. Far and away the most frequent defense to complaints of discrimination is denial by the

176. See (1939) 6 U. S. L. WEEK 889, 896. At the same time the Court was malsing this breach of contract ruling, the Board was announcing that an employer's breach of a collective bargaining contract was not an unfair labor practice, although the contract had been made with a majority union. In re Williams Coal Co., 11 NLRB, No. 49 (1939).

177. 245 U. S. 229 (1917); a case so universally criticized that it greatly accelerated passage of the Norris-LaGuardia Act.

178. See Miagruder, A Half Century of Legal Influence Upon the Dezclopment of Collective Bargaining (1937) 50 Harv. L. Rev. 1071, 10S4n (citing Lasdis, Cases o:i Labor Law (1934) 131n., 181-182, and Semaras, The Yellow-Dog Contruct (1932) 21 et seq.).

179. Most of the common types of this problem are mentioned in connection with "vicarious" discharges.

180. In re Tennessee Copper Co., 9 NLRB, No. 19 (193S) (Board's most explicit statement); Nekoosa-Edwards Paper Co., 11 NLRB, No. 54 (1939). The Bourd is rather generally sustained by the courts in this attitude. For example: N. L. R. B. $r$. A. S. Abell Co., 97 F. (2d) 951 (C. C. A. 4th, 1938) (violation of $\$ \$(1)$ ); Virginis Ferry Corp. v. N. L. R. B., 101 F. (2d) 103 (C. C. A. Ath, 1939) (violation of $\delta 8(2)$ ). A notable reversal is Peninsular \& Occidental Steamship Co. r. N. L. R. B., 98 F. (2d) 411 (C. C. A. 5th, 1938), cert. denied, (1939) 6 U. S. I. WEEK 442, wherein the court declared the emphasis must be on the conduct of high company officials, and bruahed aside as not attributable to the employer the discriminatory remarks of supervisors of high rank.

181. See (1939) 6 U. S. L. WeEK 888-89, 896. 
employer that differentiation in treatment was because of union membership or activities. Ordinarily this is done by alleging that sufficient cause motivated the action complained of. This sometimes raises one question of law (the legal sufficiency of the alleged cause), but it always raises (unless they are admitted) two questions of fact: the existence of the alleged cause; and the efficiency of the motivation, granted the sufficiency and existence of the alleged cause.

Naturally most cases turn upon the factual determinations-that is, the weighing of the evidence ${ }^{182}$ - since in most cases the employer is able to allege causes the legal sufficiency of which is beyond cavil. However, it would nevertheless be highly unrealistic to dismiss the question of sufficiency with the mere statement, even though it be made by the Stpreme Court, that "the Act permits a discharge for any reason other than union activity or agitation for collective bargaining." 183 Enough has been said herein in connection with the question of whether and what union "activities" are directly protected by Section 8(3) and the discussion of employers' problems of discipline ${ }^{184}$ to show that there are many things which theoretically might constitute sufficient cause for discharge or refusal to reinstate but which the Board as a practical matter does not recognize as such. Thus the ruling of law - sufficiency of an alleged cause - often masquerades as a determination of fact. Furthermore, although proving the existence of proper cause, or even partial motivation thereby, does not, as has been shown herein, ${ }^{185}$ establish the defense of absence of anti-union motive required by the Board, the allegation of proper cause is, for all practical purposes, the sine qua non of an effective defense. For no employer has yet appeared hardy enough - or foolhardy enough - to rest on the "sheer caprice" defense so of ten talked of by the Board. ${ }^{186}$ A summary is justified, therefore, first, of those defences which most often find favor with the Board, and, secondly, of those which do not. Defenses to reinstatement of strikers who have engaged in violence have been separately considered. ${ }^{\mathbf{1 8 7}}$

Causes which may constitute justification. "Perhaps the most common explanations offered in defense," the Board declares, "are that the em-

182. For a discussion of this problem, see Ward, Proof of Discrimination under the National Labor Relations Act (May, 1939) 7 Geo. WASH. L. Rev.

183. Associated Press v. N. L. R. B., 301 U. S. 103 (1937); see also the Finstcel opinion, (1939) 6 U. S. L. WeEK 896, 899, wherein the Court paraphrases this statement in the Associated Press case into ". . . the employer is not permitted to discharge his employees because of union activity or agitation for collective bargaining." The Court is referring, however, to the purpose of the definition of "employee" in \$2(3), and no reference is made to $\$ 8(3)$.

184. See supra pp. 1164 et seq.

185. See infra p. 1191.

186. See NLRB First Annual Report (1936) 77; NLRB Second Annual. RepORT (1937) 70; NLRB Third ANNuAl Report (1939) 65.

187. See supra pp. 1158-1159. 
ployee is inefficient, or that a drop in production required a reduction in personnel which was accomplished pursuant to criteria not anti-union in character." 188 The Board always accepts either of these as justification if proved the true cause. Even an unjustified suspicion of inefficiency, if the suspicion actually exists, ${ }^{189}$ or very minor instances of inefficiency, ${ }^{100}$ will be sufficient. Other common causes which will generally be accepted as justification, if proved, include: general insubordination, as where employee profanely told the plant superintendent that the company had had control long enough and that from then on the union was going to tell them how to run the place $;^{101}$ refusal to obey orders $;{ }^{102}$ misconduct or dangerous misconduct; ${ }^{193}$ excessive absences from work; ; $^{194}$ irresponsibility ${ }^{195}$ frequent disputes with other employees; ${ }^{100}$ disputes with supervisors and complaints of not being able to do heavy work; ${ }^{107}$ strong suspicion of dishonesty ${ }^{198}$ physical incapacity for work; ${ }^{\mathbf{1 0 3}}$ lack of seniority, or former sporadic employment; ;00 lack of raw material; $; 01$ change to new machinery which employees discharged were not shown to have been capable of operating; ${ }^{202}$ poor financial condition necessitating re-

188. These defenses may be appropriate in cases of lay-offs, discharges, individual or mass, or refusals to reinstate. Closed shop contracts as justifications are discussed infra p. 1192. NLRB THIRD ANNUAL Report (1939) 84; Int re Newport News Shipbuilding \& Drydock Co., 8 NLRB, No. 107 (1938) (general lay-off constituted justifiention despite "highly suspicious" background of violations of $\$ \S 8(1)$ and $8(2)$ ).

189. In re Seagrave Corp., 4 NLRB 1093 (1938); NLRB Tumn Anaval Reront (1939) 85.

190. In re General Chemical Co., 8 NLRB, No. 31 (1938) (discharge occurred at end of busy season, the selection being based on minor instances of inefficiency, which, however, made discharged union employee's record worse than those of employees retained).

191. In re Mock-Judson-Voehringer Co., 8 NLRB, No. 16 (1938); In re Volfenden, 12 NLRB, No. 20 (1939) (cursing employer) .

192. In re Empire Furniture Corp., 10 NLRB, No. 92 (1939); In re Triplett Electric Co., 5 NLRB 835 (1938); cf. In rc Julius Breckwoldt, 9 NLRB, No. 17 (1938).

193. In re A. H. Wirz, Inc, 9 NLRB, No. 43 (1938); In re Suron Optical Co., Ine., 11 NLRB, No. 65 (1939) (despite "considerable suspicion" of employer's motive); In re Panco-Panther Rubber Co., 11 NLRB, No. 117 (1939) ("fooling round" with girls working on dangerous machine).

194. Held "ample justification for a discharge" of an outstanding union leader. In re Timken-Detroit Axle Co., 11 NLRB, No. 18 (1939); In re Yates-American Alachinery Co., 7 NLRB 627 (1938); In rc Triplett Electrical Co, 5 NLRB $\$ 35$ (1938); cf. In re Julius Breckwoldt, 9 NLRB, No. 17 (1938) (discharge of union president for leaving shop to talk to other employees while they were working).

195. In re Cardinale Trucking Corp., 5 NLRB 220 (1938).

196. In re Newport News Shipbuilding \& Dry Dock Co., 8 NLRB, No. 107 (1933).

197. In re North Whittier Heights Citrus Ass'n, 10 NLRB, No. 113 (1939).

198. In re Wald Transfer \& Storage Co., Inc, 3 NLRB 712 (1937).

199. In re Shellabarger Grain Products Corp., 8 NLRB, No. 38 (1938).

200. In re Hamilton-Brown Shoe Co., 9 NLRB, No. 99 (1938) (despite general antiunion bias of employer).

201. In re North Whittier Heights Citrus Ass'n, 10 NLRB, No. 113 (1939).

202. In re Uxbridge Worsted Co., 11 NLRB, No. 31 (1939). 
moval of plant to another city after impasse in collective bargaining ${ }^{203}$ walk-out of essential workers, necessitating shut-down of department; ;04 hiring of new employees during strike not caused by unfair labor practices ${ }^{205}$ bona fide dispute as to interpretation of strike-settlement agreement with union $;^{206}$ bona fide construction of seniority agreement $;^{207}$ and "honest misunderstanding" that employee had secured other employment. $^{208}$ The most consistently successful defense is abolition of or discontinuance of the job formerly held, if coupled with a showing that no replacement employees have been employed. The Board. accepts this as justification even from employers having a conspicuous anti-union background. ${ }^{209}$ Another sure-fire defense, although a comparatively new one, is failure of an employee to earn, at piece rates, the minimum wage paid at the plant. ${ }^{210}$

Causes usually held no justification. No doctrine of private necessity creating even an incomplete conditional privilege is recognized by the Board in discrimination cases. ${ }^{211}$

Nor does "freedom of the press" confer privilege on press associations or newspapers to discriminate among editorial employees because of union membership. The Board and the Supreme Court both rejected an employer's contention that freedom to discriminate was a necessity of the business of news gathering. ${ }^{212}$ Another alleged business justification uniformly rejected by the Board is the contention that the other employees refuse to work with the discharged employee $;^{213}$ and the same attitude

203. In re Lengel-Pencil Co., 8 NLRB, No. 122 (1938). The most conservative court would find no opening to criticize the Board's handling of the evidence in this case. A lockout of the employees, repeated threats of liquidation of the business and of removal of the plant, and the final removal of the plant to another city wero found not to constitute discrimination to discourage union activities or collective bargaining. The Board found that the threats were motivated by the financial condition of the cmployer and that the removal of the plant resulted from an impasse in collective bargaining.

204. In re Julius Breckwoldt, 9 NLRB, No. 17 (1938).

205. Ibid.

206. In re Elkland Leather Co., 8 NLRB, No. 56 (1938).

207. In re Minneapolis-Moline Power Co., 8 NLRB, No. 82 (1938).

208. In re Ferguson Bros. Mfg. Co., 9 NLRB, No. 30 (1938).

209. In re Mt. Vernon Car Co., 11 NLRB, No. 46 (1939); In rc Acme Air Appliance Co., 10 NLRB, No. 123 (1939). Citations for this proposition could be multiplied at great length. But cf. In re Patriarca Store Fixtures, Inc., 12 NLRB, No. 11 (1939). 210. In re Yale \& Towne Mfg. Co., $10 \mathrm{NLRB}$, No. 116 (1939). See also In rc Pulaski Veneer Corp., 10 NLRB, No. 11 (1938); In re Burnside Steel Foundry Co., 7 NLRB 714 (1938); In re Marathon Rubber Products Corp., 10 NLRB, No. 59 (1938) (involving more colorful reasons for discharge).

211. In re Star Publishing Co., 4 NLRB 498 (1937), order enforced, N. L. R. B. V. Star Publishing Co., 97 F. (2d) 465 (C. C. A. 9th, 1938).

212. Associated Press v. N. L. R. B., 301 U. S. 103 (1937).

213. In re Clover Fork Coal Co., 4 NLRB 202 (1937), order enforced, Clover Forl: Coal Co. v. N. L. R. B., 97 F. (2d) 331 (C. C. A. 6th, 1938); In re General Shoe Corp., 5 NLRB 1005 (1938); In re Trawler Maris Stella, Inc., 12 NLRB, No. 50 (1939). 
is maintained even though the reason given for the refusal is allegedly unconnected with the union membership or activities of the employee. ${ }^{218}$

Business reasons of one sort or another are generally the justification alleged for shutting down the plant where a "mass discharge" is alleged by the Board's complaint. The employer's claimed fear that a "sitdown" strike may occur has never been accepted by the Board as an excuse. ${ }^{215}$ Similar treatment has been accorded the employer's contention that the plant was closed because labor trouble had influenced the mental attitude of the employees and caused them to produce inferior goods, resulting in many returns and complaints. ${ }^{210}$ Calling a strike, or a partial strike, or managing a non-violent sit-down strike, ${ }^{117}$ has not heretofore been considered by the Board as a justifiable basis for differentiation in treatment of the employees who did so. The employee's conduct as an individual, as well as his conduct as a union member, frequently is the basis for justification. But his insubordination is never regarded as an excuse if it were provoked by the employer. ${ }^{218}$ And the use of profane or indecent language, even by a woman employee, will not constitute justification where such language is not uncommon, ${ }^{210}$ although the Board hastened to declare that such holdings are not intended to impinge on the employer's right to make rules against use of such language. $\simeq 0$ Refusal to work on an extra shift out of regular turn will not be recognized as a basis for discharge where no written rules governed the subject and the employees believed that they had a right to refuse; 201 nor will a refusal to work on Saturday in violation of a union rule be

214. In re Nekoosa-Edwards Paper Co., 11 NLRB, No. 42 (1939). The Board flatly refused to believe the stipulated testimony of 50 employees that they would refuse to work with the discharged employee because he had complained to the company, in their opinion unfairly, against the plant superintendent.

215. E.g., In re National Motor Bearing Co., 5 NLRB 409 (1935); Hopwosd Retinning Co., 4 NLRB 922 (1938), order enfored with minor modificalions, N. L. R. B. v. Hopwood Retinning Co., Inc, 98 F. (2d) 97 (C. C. A. 2d, 1938); In re Patriarea Store Fixtures, Inc., 12 NLRB, No. 11 (1939).

216. In re Somerset Shoe Co., 5 NLRB 486 (1938); In re Phillips Granite Co., 11 NLRB, No. 72 (1939).

217. In re Harnischfeger Corp., 9 NLRB, No. 64 (1938).

218. Employer refused grievance committeeman use of phone to inform union official of result of conference, and thus "provoked" employee into leaving building to telephone. Employee "properly took a few minutes off from work to confer with" the union official. In re Art Crayon Co., Inc., 7 NLRB 102 (1938).

219. "A factory wash room is not a place where decorum in the use of langusge is commonly observed, and from the obscenities used by other witnesses testifying at the Hearing, we are satisfied that the words attributed to MIrs. Kendy did not create the furore which the respondent's witnesses, calmly repeating her words in open court, would have us believe." In rc Federal Bearings Co., Inc., 4 NLRB 467, 468 (1937).

220. In re Titmus Optical Co., 9 NLRB, No. 94 (1938): "An employer has a right to discharge an employee for using obscene language in his plant if he sees fit to do so," but such alleged reason is found to have been a pretext under the circumstances.

221. In re Dunbar Glass Corp., 6 NLRB 789 (1938). 
regarded as justification where the employer did not usually operate its plant on Saturdays, or a refusal to work on Labor Day, in order to attend a union rally, although local custom was to work on that day and employer gave warning in advance of discharge of all who failed to report. ${ }^{222}$ The employer's fear that an employee "might commit sabotage" because his brother had been discharged was denied sufficiency as a defense. $^{223}$

The closed shop proviso: a spectal defense under Section 8(3). The proviso clause to Section $8(3)^{224}$ establishes a special defense to complaints of discriminatory discharge by creating a privilege in the employer to act pursuant to a contract which comes within the protection of that clause. This special defense, therefore, is always dependent upon whether the contract relied upon meets the strict requirements of the proviso. Two clauses of the proviso narrowly restrict (1) the type of contracts protected and (2) the type of labor organization which may be a party thereto.

(1) Strictly construed - and provisos should be strictly construed the closed shop clause protects from the several proscriptions of Section 8 (subsections (1), (2), and (3)) only the closed shop or all-union shop provisions of contracts made with a proper labor organization party. Nothing more than that, and nothing less ${ }^{225}$ than that, is protected by the words of the proviso: "an agreement with a labor organization . . . to require as a condition of employment membership therein." Thus, a check-off agreement is not within the language of the proviso whether or not contained in the same contract with a valid closed shop agreement. The Board has not yet decided the question of whether a check-off agreement is protected by implication of the proviso. ${ }^{226}$ It generally proceeds, however, by assuming that the proviso would protect a check-off agreement if made with a proper labor organization party. ${ }^{227}$ But the Board has emphatically held that a check-off agreement not protected by the proviso is a violation of Section $8(1)$, (2), and (3). ${ }^{228}$ As to Section $8(3)$, the performance by the employer of the agreement imposes a "condition" of employment "obviously discriminatory in favor of" the contractee union. ${ }^{220}$

222. In re Hyman Levy, 11 NLRB, No. 80 (1939); In re Good Coal Co., 12 NLRB, No. 19 (1939).

223. In re Fashion Piece Dye Works, Inc., 6 NLRB 274 (1938).

224. The proviso clause is set out in note 65 , supra.

225. See In re Clinton Cotton Mills, 1 NLRB 97, 110 (1935).

226. See In re National Electric Products Corp., 3 NLRB 475, 486n (1937).

227. In re Williams Coal Co., 11 NLRB, No. 49 (1939); cf. National Electric Products Corp., 3 NLRB 475 (1937) (agreement to check-off dues whether or not employee checked was a member of the contractee union).

228. In re Williams Coal Co., 11 NLRB, No. 49 (1939).

229. In re National Electric Products Corp., 3 NLRB 475, 486 (1937). 
The problem of whether the proviso would protect a preferential shop contract is also a delicate one. Strictly construed, the proviso would afford no protection for this type of agreement, since a preferential shop provision does not require membership in the contractee union as a condition of employment, but merely gives members of the contractee union preference in hiring when vacancies exist and members are available to fill them. The circuit court of appeals held a preferential contract to be within the protection of the proviso and valid and binding on the employer in Peninsula \& Occidental Stcamship Company \%. National Labor Relations Board. ${ }^{230}$ There was no discussion therein of the instant problem, however. The implication of protection seems less strained in the case of preferential agreements than in relation to the check-off, but the argument that the greater includes the lesser lost much of its force by reason of the Board's explanation in the Clinton Cotton Mills case $^{23 I}$ of the function of the proviso. In any event, the Board has held, a preferential shop contract is no defense to discharges because such contracts do not require the discharge of employees, but only the granting of preference in filling vacancies. ${ }^{232}$ Thus the problem under discussion can arise only in connection with alleged discrimination in regard to hire, and has no bearing on tenure or discharges.

(2) The first requirement of a proper labor organization party to a closed shop contract is contained in the "parenthetical clause," which requires that the labor organization be "(not established, maintained, or assisted by any action defined in this act as an unfair labor practice)" (italics supplied). The emphasized language is the condition which prevents the doctrine of the Supreme Court in the Consolidated Edison case $^{233}$ from applying to closed shop contracts. Under the rule of that case it appears that the Board must make a finding of violation of Section $8(2)$ before it can set aside as violative of the Act a "beneficial" contract not containing a closed shop clause. Apparently for reasons of policy, the Board has never yet found a violation of Section $8(2)$ in connection with a nationally-affiliated union, although the same type of employer-conduct has many times existed with respect to which the Board would have made such a finding in connection with an unaffiliated union. ${ }^{234}$ But no such finding of company domination need be made in

230. Peninsular \& Occidental S. S. Co. v. N. L. R. B., 98 F. (2d) 411,414 (C. C. A. 5th, 1938); followed in Waterman Steamship Corp. v. N.L.R. B., 4 L. R. R. 276 (C. C. A. 5th, 1939).

231. In re Clinton Cotton Mills, 1 NLRB 97 (1935).

232. In re Waterman Steamship Corp., 7 NLRB 237 (1938). A contract giving the union the right to make selections for discharge is treated as a closed-shop contrast rather than a preferential contract. In re Highway Trailer Co., 3 NLRB 591, 609 (1937).

233. See note 33 , supra.

234. . The facts showed a clear violation of $\$ 8(2)$ in In re Consolidaled Edison case, (1938) 6 U. S. L. WeEK 425, and in the In re Nalional Elcetric Produts Corp. case, 
the case of a closed shop contract, if the contractee union has been assisted by employer conduct in violation of Section 8(1) or (3). Thus several months after the Consolidated Edison decision, the Board with justifiable confidence proceeded to declare void a closed shop contract between a large employer and an A. F. of L. union. ${ }^{235}$ Obviously a closed shop contract is void if there is a proper finding of violation of Section $8(2) .{ }^{236}$ The proviso does not apply although the acts of assistance by the employer occurred before the effective date of the Act. ${ }^{237}$ Such acts could not, of course, be regarded retroactively as constituting unfair labor practices, but the conduct is nevertheless "defined as" an unfair practice by the Act.

The second requirement of a proper labor organization party is contained in the conditional clause, "if such labor organization is the representative of the employees as provided in Section 9(a), in the appropriate bargaining unit covered by such agreement when made." Section 9 (a) is the famous majority rule provision, so all of the familiar problems of majority representation are thus introduced into the closed shop proviso. These include definition of the appropriate bargaining unit, including the constituency thereof, and proof of majority, inclucling a particular time element. The first problem, then, is whether the agreement covers an appropriate unit, which must be determined by the Board under the principles laid down in Section 9(b) - a special subject having its own extensive body of case law. The constituency of the unit, however, has a special relation to the subject of the closed shop contract as a defense to an alleged violation of Section 8(3). In the case of a strike, the Board holds, the unit includes employees on strike as wcll as those who have returned to work, and the contractee union must represent an uncoerced majority of both counted together. ${ }^{238}$ This is fair enough; the difficult problem will arise where substantially all of the original employees are on a strike not caused by any unfair labor practice, and the employer has hired a full crew of replacements. This presents three possibilities for the unit: the replacement employees; replacement $\mathrm{cm}$ -

3 NLRB 475 (1937), but the Board "found" no violation. In the In re Mt. Vernon Car $M f g$. Co. case, 11 NLRB, No. 46, (1939), no violation of $\$ 8(2)$ was charged in the complaint, but it would have been charged if the union concerned was not nationallyaffiliated. Here again, as in the case of $\$ 8(3)$, the Board does not enforce the Statute as it is written.

235. In re Mt. Vernon Car Mfg. Co., 11 NLRB, No. 46 (1939).

236. The Board's original definitive consideration of the proviso arose in this connection in In re Clinton Cotton Mills, 1 NLRB 97 (1935). Very little substantive interpretation had been added by the Board until the In re Williams Coal Co. case, 11 NLRB, No. 49 (1939); In re United Fruit Co., 12 NLRB, No. 49 (1939).

237. In re Clinton Cotton Mills, 1 NLRB 97 (1935); In re Williams Coal Co., 11 NLRB, No. 49 (1939). "Otherwise an employer could perpetuate an organization of his creation prior to July 5, 1935." NLRB Third ANNuAd Report (1938) 90.

238. In re Williams Coal Co., 11 NLRB, No. 49 (1939). 
ployees plus the strikers; and the strikers alone. For purposes of representation, the Board has adopted the third possibility, holding that the replacement employees are not entitled to vote in an election conducted under Section $9(\mathrm{c}){ }^{239}$ Consistency would require the same holding in connection with a closed shop contract, since the problem is identical are the replacement employees entitled to representation, or can they be held to have no rights under the Act merely because they are replacements, and even though the strike was not caused by any unfair labor practice. The Board's answer seems harsh; furthermore, the Supreme Court has declared that the employer has an unqualified right to hire replacement employees in the case of a strike not caused by unfair labor practices, and that they need not be displaced to reinstate the strikers. ${ }^{210}$

The requirement of proof of a majority is not to be met by merely showing majority membership in the contractee union, or a majority designation thereof. ${ }^{241}$ The majority must be an "uncoerced majority," and is "vitiated" if there has been interference by the employer in assisting the contractee union. ${ }^{242}$ A truly subtle employer who wished to forestall a closed shop demand by a strong union might naively render the union some rather obvious but not particularly efficacious assistance, and then regretfully proclaim that he had been advised by counsel that he was precluded from entering such a contract, as his enforcement of it would constitute discrimination under the Act, since it would not be protected by the proviso.

The time when the majority must exist is rather clearly stated in the words of the proviso - "when (the agreement was) made." This question arises frequently, and the Board's answer is taken directly from the statutory words. ${ }^{243}$

Great difficulty is inherent in the question presented to the Board by a change in affiliation of a majority of the members of a union having an existing closed shop contract. ${ }^{244}$ In the cases so far decided, the courts have been willing to apply the proviso in a number of cases wherein the

239. In re A. Sartorious, 10 NLRB, No. 37 and No. 37a (193S).

240. N. L. R. B. v. Mrackay Radio \& Tel. Co., 304 U. S. 333 (1938).

241. E.g., In re Electric Vacuum Cleaner Co., 8 NLRB 112 (1938) (contraet signed by 964 out of 1,032 employees); In re Missouri-Arkansas Cosch Lines, 7 NLRB 185 (1938) ; Izt re Serrick Corp., 8 NLRB 621 (1938). The requirement is met by a showing that a majority of the employees went on a strike conducted by the contractee Union. In re United Fruit Co., 12 NLRB, No. 49 (1939).

242. Cases cited supra note 327; In re National Electric Products Corp., 3 NLRB 475 (1937).

243. In re Merry Shoe Co., 10 NLRB, No. 32 (1938), order ztilhdrazzs uthout explanation, Jan. 27, 1939.

244. In re $\mathrm{AI} \& \mathrm{MI}$ Woodworking Co., 6 NLRB 372 (1938), order rev'd, AI \& MC Woodworking Co. v. N. L. R. B., 4 L. R. R. 36 (C. C. A. 9th, Feb. 17, 1938); In re Smith Wood Products, Inc, 7 NLRB 950 (1938). For a comprehensive discussion see (1939) 48 YALE I. J. 1053. 
Board had found it to be no defense. ${ }^{245}$ In at least one case, however, the Board was willing to hold that the proviso applied, although the circumstances concerning the ready concession of a closed shop were "somewhat suspicious," where the contract was signed by the employer after check of the majority status of the union, and upon the union's insistence. ${ }^{246}$ The Board has set up one rather mysterious and extrastatutory but not unfair condition to reliance upon the proviso: employees must have notice and full information concerning the closed shop agreement, so that they may distinguish between unlawful acts of the employer and action taken pursuant to a legal labor organization contract. ${ }^{247}$

Miscellaneous and technical Defenses. A showing by "reliable evidence" of compliance with the trial examiner's recommendations as to employees found by him to have been discriminatorily discharged has been held sufficient basis for dismissal of the complaint as to those persons. ${ }^{248}$ Dissolution of a corporate employer prior to enforcement of the Board's order is not regarded as a defense if there is a successor corporation. $^{249}$ A much more difficult problem is presented where the employer goes out of business entirely, and has no successor, or goes into a different line of business. The Board declared itself "unable" to order an employer whose unfair labor practices had caused a strike to reinstate the striking employees, where during pendency of the strike he had gone into a different line of business requiring a different type of labor. ${ }^{250}$ The familiar doctrine of res adjudicata undoubtedly will apply in a proper case under the Act, but it has no application, the Board has held, where the former case was dismissed before hearing on the merits, although the charges were withdrawn with the consent of the Board's regional director. $^{251}$ It is no defense that employees discriminatorily dischatrged have failed to act in mitigation of damages, ${ }^{252}$ nor that they refused an

245. N. L. R. B. v. Lion Shoe Co., 97 F. (2d) 448 (C. C. A. 1st, 1938); Peninsular \& Occidental S. S. Co. v. N. L. R. B., 98 F. (2d) 411 (C. C. A. 5th, 1938), ccrt. dcnicd, 59 Sup. Ct. 248 (1938); M \& M Woodworking Co. v. N. L. R. B., 6 NLRB 372 (1938).

246. In re United Fruit Co., 12 NLRB, No. 49 (1939).

247. See In re Electric Vacuum Cleaner Corp., 8 NLRB 112 (1938); cf. In re United Fruit Lines, Inc., 12 NLRB, No. 49 (1939).

248. In re Serrick Corp., 8 NLRB 621 (1938).

249. In re The Timken Silent Automatic Corp., 11 NLRB, No. 71 (1939).

250. In re N. Kiamie, 4 NLRB 808 (1938); and in In re Shell Petroleum Corp., 10 NLRB, No. 60 (1938), the Board held that reinstatement of employees found to have been discriminatorily discharged would not be necessary, in view of a fire which had destroyed the plant at which they were employed, if the employment of persons hired to replace the discharged employees ceased permanently as a result of such fire. The Board provided, however, that if the replacement employees were retained after the fire or after an interval were reinstated elsewhere by the employer, the reinstatement of the discharged employees should not be denied.

251. In re Shuron Optical Co., Inc., 11 NLRB, No. 65 (1939).

252. N. L. R. B. v. Carlisle Lumber Co., supra note 9; Western Felt Works, supra note 92 . 
interim offer of reemployment by the respondent employer in different positions. ${ }^{253}$ The status of the Board's doctrine, which had some support in the courts, that "unclean hands" on the part of a union or employees will not avail the employer as a defense, ${ }^{234}$ has been thrown in doubt by the Fansteel decision. The Board approves another angle of the clean hands doctrine, however, and holds that an employee who offered to assist an employer to violate the Act is entitled to no relief under the Act. ${ }^{255}$

The equitable principle of laches is not applicable to proceedings on a complaint of unfair labor practices under the Act, the Board has held. The lapse of two years and seven months between the unfair practice and the complaint based thereon, does not bar or estop maintenance of the proceeding, but where it is the complainant union instead of the Board which has caused a long delay, however, a modified form of the doctrine of laches is applied by deducting from back pay the period prior to the filing of the charges. ${ }^{250}$ The Fifth Circuit Court of Appeals rather naively placed itself in an ambiguous position by declining to punish an employer for contempt for failure to comply with the order of that court enforcing a Board order requiring reinstatement of an employee "without discrimination against" two other union employees already employed, on the ground that the employer was "placed in a dilemma by an order which was self-contradictory" in that it entitled all three employees to jobs whereas only two are needed at the plant..957 The court might well have subjected the Board's order to such scrutiny before issuing its own decree of enforcement. It is no defense for failure to comply with a back pay order that the Board did not determine the amount of back wages. Amounts "can best be determined by the parties involved, who can calculate the same by applying the standard set out in the Board's order. Only if they are unable to do so will it be necessary for the Board to fix the amounts." 258

A vital distinction is made by the Board in comnection with the defense of settlement between settlement agreements between the parties alone and agreements to which an agent of the Board is a party. Consistently the Board has held that a settlement or strike settlement agreement be-

253. In re Eastern Footwear Corp., 8 NLRB, No. 154 (1938).

254. N. L. R. B. v. Carlisle Lumber Co., 99 F. (2d) 533 (C. C. A. 9 th, 1938), ccrt. denied, (1939) 6 U. S. L. WeEK 914; N. L. R. B. v. Hearst, 4 L. R. R. 165, 163 (C. C. A. 9th, Mar. 23, 1939).

255. In re Thompson Cabinet Co., 11 NLRB, No. 99 (1939).

256. In re Colorado Milling Co., 11 NLRB, No. 16 (1939); Back pay was ordered for a period of three and one-half years. But cf. In re Cherry Cotton Mills, 11 NLRB, No. 44 (1939) (two-year period between transfer of case from trial examiner to NLRB without an intermediate report, and decision of NLRB, was excluded in computation of back pay). In re Inland Lime \& Stone Co., 8 NLRB, No. 116 (1938).

257. N. L. R. B. v. Bell Oil \& Gas Co., 98 F. (2d) 405 (C. C. A. 5th, 1938).

258. N. L. R. B. v. Fashion Piece Dye Works, 100 F. (2d) 304 (C. C. A. 3d, 1938); cf. N. L. R. B. v. Carlisle Lumber Co., supra note 9. 
tween an employer and the complainant union is no bar to prosecution of the unfair labor practice proceeding or an order commanding reinstatement and back pay. ${ }^{259}$ The Board properly will brook no encroachment upon the exclusive jurisdiction conferred upon it by Section 10(c) to remedy unfair labor practices. The Board, representing the United States, is a party in interest in all proceedings relating to unfair labor practices under the Act. ${ }^{200}$ All compromise or settlement agreements between the parties will, therefore, be "closely scrutinized" by the Board, although in a proper case it may exercise its discretion and refuse to disturb the settlement. ${ }^{261}$ If the Board finds that the agreement will not tend to effectuate the policies of the Act, no weight will be given to the agreement. ${ }^{262}$ An agreement by a union which purports to bind it from filing charges under the Act on behalf of employees is contrary to the policy of the Act, and therefore of no effect whatsoever upon the union's power so to initiate proceedings before the Board. ${ }^{263}$ Nor can employees be estopped from assertion of their rights under the Act by a so-called strike-settlement agreement in fact dictated by the employer although purportedly the result of collective bargaining. ${ }^{264}$ Necessarily, settlement agreements are given full effect where an agent of the Board participated. ${ }^{265}$

\section{CoNClusion}

Effective administration of the Act as a single piece of legislation requires that the Board have the respect and confidence of both management and labor; the broader objectives of the Statute can be achieved through no other means. The specific purpose of the Act is to promote collective bargaining; but its ultimate end is that the nation's labor problem may be solved without resort to the stultifying status quo of dictatorship or the senseless suffering of revolution. For change has so outrun time during the past decade that the term "labor problem" has a new content. It is broader - and considerably more intense. Throughout the world there is an inevitable force behind the demand of industrial and clerical workers for the social security not heretofore available below the wealthier middle classes. Depressions and recessions have run up the head of pressure behind this demand. The demand has in turn instilled into the old concept of the labor problem new economic and political

259. In $r e$ Kelly-Springfield Tire Co., 6 NLRB 325 (1938); In re Ingram Mfg. Co., 5 NLRB 908 (1938); In re Crossett Lumber Co., 8 NLRB, No. 51 (1938).

260. In re Ingram Mfg. Co., 5 NLRB 908 (1938).

261. Id.

262. In re Shuron Optical Co., 11 NLRB, No. 65 (1939).

263. In re Ingram Mfg. Co., 5 NLRB 908 (1938).

264. In re Crossett Lumber Co., 8 NLRB, No. 51 (1938).

265. In re Shenandoah-Dives Mining Co., 11 NLRB, No. 67 (1939). 
problems of distribution of wealth, and of mass markets. The demand must be met. The problem must be solved. It is the policy of the United States to rely upon the collective bargaining process to make the advances to meet this demand. ${ }^{266}$

To shape the collective bargaining process as an effective tool, Congress found it necessary to lift it entirely out of the field of the common law. That field had become too confused for proper development of labor law. Confusion is commonplace enough in our jurisprudence. Little wonder: it is split by evanescent boundaries of state and national jurisdiction; it teems with opposing state rules varying through 48 shades of inconsistency; it stirs with embryo uniform laws well enough conceived but foredoomed to interminable gestation. But the common law of labor towered monstrously above this confusion.

Thus it was that the great Supreme Court decisions of April, 1937, held infinite promise. They made possible under the Act a single consistent body of law applicable to almost all important industries insofar as the entire collective bargaining process was concerned. Then the Board began administering the Act through a process of reading things into it which just were not there - such as direct protection by Section $8(3)$ of all types of "union activities." To halt this tendency the Supreme Court evoked tests of vague, indefinable and elastic meaning: "unlawful strike;" "tort;" "breach of contract;" "right of selection." These tests may end the unifying influence of the jurisdictional decisions of April, 1937. Certainly they will not promote "respect and confidence" between management and labor. In the long run employers would profit more through a consistent and predictable body of law governing the collective bargaining process than they will in standing on supposed rights under the enigmatic decisions of February 27, 1939. And if labor is patient enough to bargain collectively under protection of the Act, it will need no protection for acts of violence.

The Board has gone too far in one direction; the Court too far in another. Happily the solution is simple: if each gives ground they will meet at the Act as it is written; let each use the criteria of the Act; let the Board not create extra-statutory unfair labor practices; let the Court not revive those tests of "legality" and "right" which long ago emasculated the common law of labor and left it an impotent thing - worse than futile for the task of providing "ring, rules, and referee" for the battle of this century.

266. Declaration of Policy in $\S 1$ of NLRA; cases cited supra note 45. 